\title{
Kernos
}

Revue internationale et pluridisciplinaire de religion grecque antique

$29 \mid 2016$

Varia

\section{I.Iasos 220 and the regulations about the priest of Zeus Megistos}

A new edition

\section{Roberta Fabiani}

\section{(2) OpenEdition \\ 1 Journals}

Electronic version

URL: http://journals.openedition.org/kernos/2396

DOI: $10.4000 /$ kernos.2396

ISSN: 2034-7871

Publisher

Centre international d'étude de la religion grecque antique

\section{Printed version}

Date of publication: 1 October 2016

Number of pages: 159-184

ISSN: 0776-3824

\section{Electronic reference}

Roberta Fabiani, «I.lasos 220 and the regulations about the priest of Zeus Megistos », Kernos [Online], 29 | 2016, Online since 01 October 2019, connection on 17 November 2020. URL : http:// journals.openedition.org/kernos/2396; DOI : https://doi.org/10.4000/kernos.2396

This text was automatically generated on 17 November 2020.

Kernos 


\title{
I.Iasos 220 and the regulations about the priest of Zeus Megistos
}

\author{
A new edition
}

Roberta Fabiani

I am indebted to Jan-Mathieu Carbon, whom I thank, for his precious suggestions and criticism.

\section{The stone at the British Museum and the text inscribed on it}

1 Among the inscriptions from Iasos, I.Iasos 220 is particularly well known to scholars of ancient religion. The text, which belongs to the Classical period (see below for its dating), contains regulations about the honorary portions due to the priest of Zeus Megistos on occasions of different types of $\theta v \sigma i ́ \alpha$ offered by citizens, metics or foreigners. This, and other documents, demonstrate that, at least in the $4^{\text {th }}$ century BC, the cult of Zeus Megistos was one of the most important cults in the city. ${ }^{1}$

2 The inscription, today held at the British Museum, was published in 1890 by Edward Lee Hicks in the third volume of the series Collection of Ancient Greek Inscriptions in the British Museum (GIBM 440). ${ }^{2}$ The inscription was donated to the British Museum by the Duke of St. Albans along with four other inscriptions, all of great aesthetic quality and of notable historical or documentary importance. ${ }^{3}$ The stones were taken to London after they had been removed from Iasos under the supervision of Sir Charles Thomas Newton in 1872, during the Duke's journey aboard the yacht Xantha - a journey about which we are unfortunately poorly informed. ${ }^{4}$ Hicks records that at the time they arrived at the Museum, the letters of this particular inscription were still painted, one line in red, the next in blue, the only one of its kind from Iasos to date. Despite the difficulty of preserving it, many other examples of such bichromy can be found on inscriptions of different kinds, from different periods, both Greek and bilingual, all over the Greek world - from mainland Greece to Asia Minor and in areas of contact with other cultures. ${ }^{5}$ It seems reasonable to think that the double color served to enhance the 
readability of the texts. In our document this hypothesis is further supported by the significant size of the letters. ${ }^{6}$

The text is carved on a large, elongated and nearly complete limestone block, which was part of a wall structure (Fig. 1). ${ }^{7}$ The central section on the front has been chiselled away, to a width of around $61 \mathrm{~cm} .{ }^{8}$ This intervention, carried out at a later stage, was not performed to connect the block with an adjoining wall: at the upper edge, the removal of the surface ceases immediately above the line of writing and therefore a thin part of the surface still remains, which has been not chiselled away; at the bottom, the chisel marks become much more widely spaced until they practically disappear approximately $5-6 \mathrm{~cm}$ from the edge of the stone, where the inscription ends, and they continue to the right, roughly following the vacat below the inscription. This was thus an intentional action aimed at destroying the inscription. The two parts of the inscription that survived must have been invisible when the central part was chiselled away: the parts closest to the edge are, in fact, completely free of signs of surface corrosion and remains of a very fine plaster are preserved, especially on the right side, filling the trough of the letters at certain points and which must have originally covered the inscribed surface. The information that Hicks provides in the editio princeps of the text probably explains these peculiarities. He reports that the stone is "a slab of blue marble, formerly used as the lintel of a window in a Byzantine building". ${ }^{9}$ One may presume that the central part of the stone remained visible while the two sides were covered, perhaps by two pillars. In order to prevent the inscription from being seen, the central part of the stone was thus chiselled. It is impossible to know where in Iasos this "Byzantine building" stood: the indication provided by Hicks is too general.

The palaeography suggests a fairly early date for the inscription. The most secure comparanda are from the first quarter of the $4^{\text {th }}$ century BC, but a slightly earlier dating cannot be excluded. ${ }^{10}$

The text published by Hicks is as follows:

\begin{tabular}{|c|c|}
\hline & 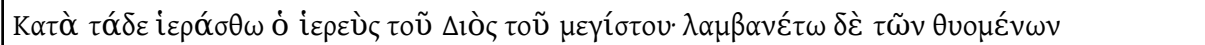 \\
\hline & 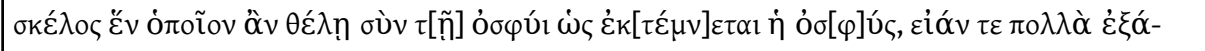 \\
\hline & 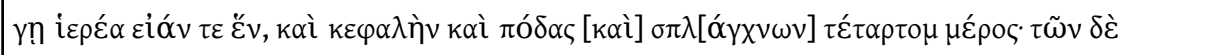 \\
\hline 4 & 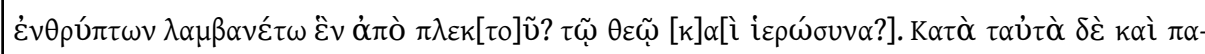 \\
\hline & 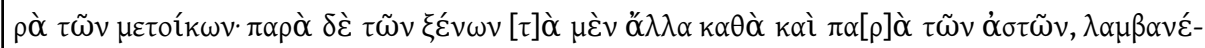 \\
\hline & 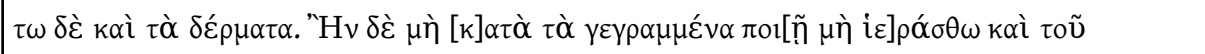 \\
\hline & 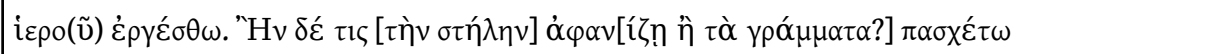 \\
\hline 8 & 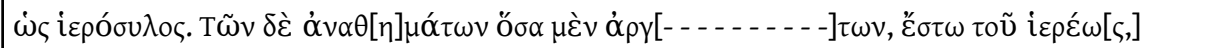 \\
\hline & 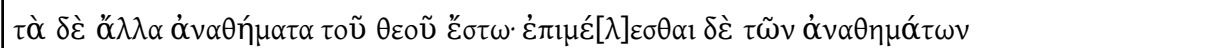 \\
\hline & 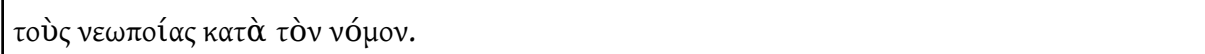 \\
\hline
\end{tabular}

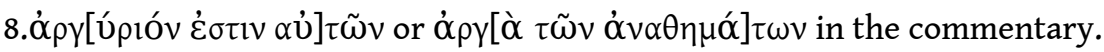

6 In 2010 Massimo Nafissi and I, together with Dr. Arch. Nicolò Masturzo - to whose competence I am indebted for some of the observations on the stone's complex sequence of reuse - undertook a first-hand re-examination of the stone, and were 
permitted to produce a paper squeeze of it. We were able to confirm the results of the exceptional expertise of the then Reverend Hicks, which we greatly admired. The future Bishop of Lincoln reconstructed the central part of the text, which is almost completely lost, on the basis of very modest traces, and did so with great acumen. Following the editorial habits of his time, Hicks rendered the text differently from how we would today. Sometimes he presented letters as if they were visible, although they are not, and at other times he supplemented letters which can be seen. Ultimately his reconstructions are generally correct, however, and we have recorded only a few small divergences in our own reading (see below).

7 Above all, our work on the stone allowed us to conclude that some later emendations by other scholars were not well-founded. After Hicks published the inscription in GIBM, the text was included in various other collections. ${ }^{11}$ In regards to editorial choices, we should note the contributions by Dittenberger, in the second edition of the Sylloge as no. 602, and by Sokolowski, who included the inscription as no. 59 of his Lois sacrées d'Asie Mineure. Neither Dittenberger nor Sokolowski carried out a direct examination of the stone. Dittenberger made very small changes to Hicks' text. At 1.4, after $\tau \tilde{\omega} v \delta \grave{\varepsilon}$

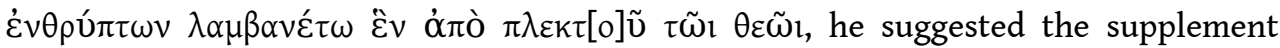

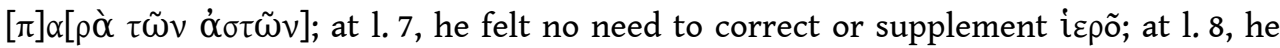

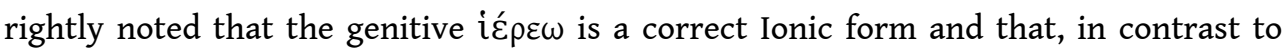
what Hicks thought, we should not assume the oversight of a sigma by the stonecutter. Widely divergent supplements (see below for more details) were proposed by F. Sokolowski for the most problematic lines (4, 7 and 8). It is Sokolowski's version of this document that is generally adopted and cited today, since it has been accepted by W. Blümel in his collection of the inscriptions of Iasos.

8 As I indicated above, it is to be stressed that all editions of the text inscribed on the stone stored in London, whether Hicks', Dittenberger's or Sokolowski's, give a rather optimistic impression of the stone's state of preservation. This misleading impression has had an ongoing influence in all publications, even in the more recent ones. This is due ultimately to the method of transcription adopted by Hicks, who remained until recently the last editor to have read the stone. Since his method does not correspond to the practice and editorial standards to which we are accustomed today, it is useful to show how the text looks and what the stone really allows us to read:

\begin{tabular}{|c|c|}
\hline & 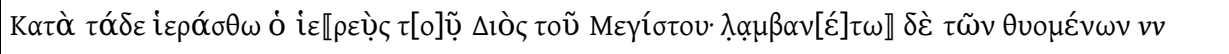 \\
\hline & 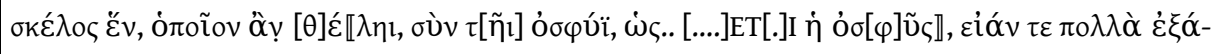 \\
\hline & 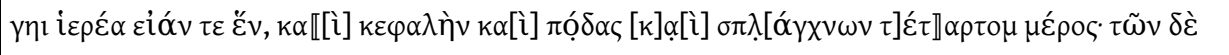 \\
\hline 4 & 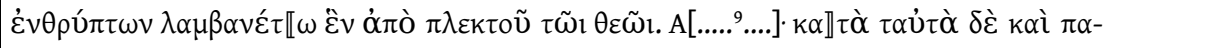 \\
\hline & 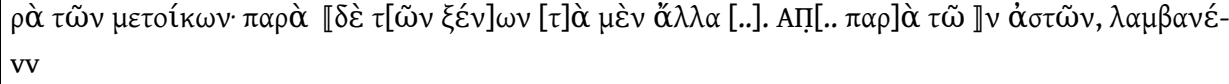 \\
\hline & 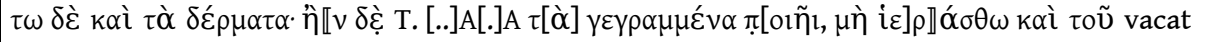 \\
\hline & 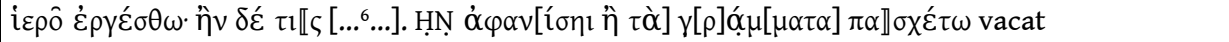 \\
\hline 8 & 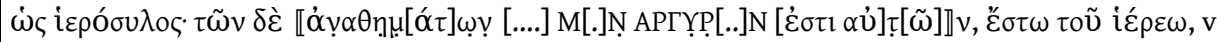 \\
\hline & 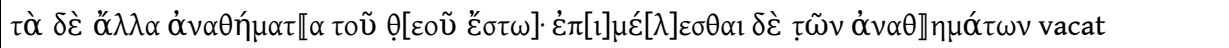 \\
\hline
\end{tabular}




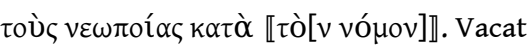

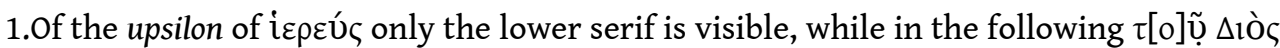
the lower serif and part of the right oblique stroke of the fork of the upsilon is to be seen. As for the first two letters of $\lambda_{\varphi} \alpha \mu \beta \alpha v[\varepsilon] \tau \omega$ : of the lambda, part of the left oblique stroke remains, while of the alpha, all the outside is detectable, but the horizontal bar is not.

2.The theta of $[\theta] \bar{\varepsilon} \llbracket \lambda \eta \imath$ is today no longer visible on the stone: it might nonetheless have been identified by Hicks, because the fracture of the stone seems to have expanded in recent times. After $\dot{\omega} \varsigma$, the stone shows part of a vertical upright stroke; part of another vertical upright remains of the next letter.

3.The iota of $k \alpha[i]$ is today no longer visible; it may have been read by Hicks, for the same reason as stated regarding line 2. As for $\pi$ ó $\delta \alpha \varsigma$, parts of the circumference of the

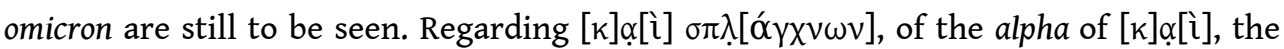
outer shape is almost completely verifiable; of the lambda in $\sigma \pi \lambda\left[\alpha \alpha_{\gamma \chi \chi} \nu \omega v\right]$, only the upper part of the triangle can still be seen.

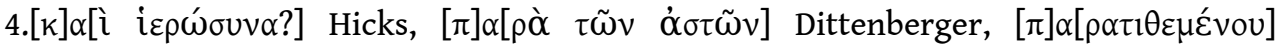
Sokolowski. Immediately after $\theta \varepsilon \tilde{\omega} \iota$ an upright stroke is recognizable.

5.Of the letter preceding $\alpha \pi$, it is possible to see the upper part of a round letter. Of the pi, the left vertical and a little stretch of horizontal bar are clearly to be seen. On the readings of this line, see also below.

6.As for $\delta \grave{\varepsilon}$, the vertical stroke and the upper horizontal bar of the epsilon can be seen. After the following tau, an upright stroke is completely visible, which could be an iota, but this remains uncertain because it lies so close to a fracture that one cannot exclude the possibility that the letter had other elements to its right. Of the $p i$ in $\pi[0 i \tilde{\eta} 1$, only the upper left corner is recognizable.

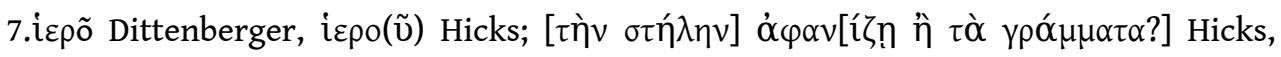

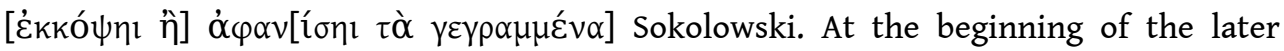
chiselling, the sigma is certain, and is followed by an illegible section of the text, which mostly corresponds to a fracture of the stone. The first recognizable letter is a triangular one, after which two vertical strokes are found, probably the remains of an eta; the upper part of a vertical stroke connected to an oblique element then follows, very probably remnants of a $n u$. Of the first alpha in $\gamma[\rho] \alpha \underline{\alpha} \mu[\mu \alpha \tau \alpha]$, we can see the upper part of the triangle.

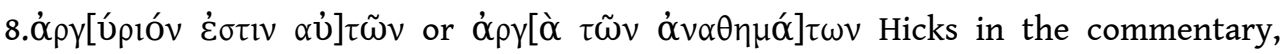

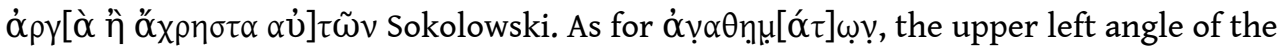
first $n u$ is recognizable; of the eta, the first upright stroke and the upper left part of the second one; of the $m u$, only the first upright stroke; of the omega, we see the upperright section of the circumference; and of the final $n u$, the first vertical stroke and part of the oblique stroke. One may suppose that the letter immediately preceding АРГ is $n u$, since the upper section of an upright stroke, the connected oblique stroke, and the upper part of a second vertical are visible. After the gamma of АРГ, there is an oblique stroke that descends from the top downwards in the right direction, probably the left oblique stroke of an upsilon; then, high above the line, traces are visible that look like the right top part of the loop of a rho. As for $\alpha \dot{u}] \tau[\tilde{\omega}] \rrbracket \nu$, only the lower part of the

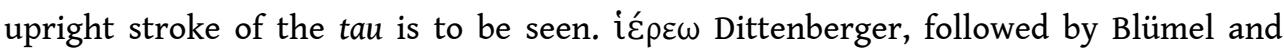
McCabe, i $\varepsilon \rho \varepsilon ́ \omega[\varsigma]$ Hicks 
9.of the theta of $\Theta[\varepsilon \circ \tilde{v}]$, the left part of the circumference is visible; of the tau of $\tau \tilde{\omega} \nu$, it is possible to identify only the lower part of the vertical stroke.

9 In general, this re-examination allows us to confirm Hicks' readings and supplements and reject the new proposals by Sokolowski. But we shall still postpone somewhat our final reading of the text, since new elements have come to light.

\section{A new fragment from lasos}

Our knowledge of the text was unexpectedly expanded a year after our visit to London During the 2011 excavation campaign, at that time led by Marcello Spanu, a fragment of a grey limestone stele was discovered in the Byzantine levels of the excavation of the north stoa. ${ }^{12}$ The stele (inventory no. 8555), mutilated on all sides, has the following measurements: width $20 \mathrm{~cm}$, height $32 \mathrm{~cm}$, maximum preserved thickness $6.7 \mathrm{~cm}$, height of the letters $1.2 \mathrm{~cm}$, line spacing $0.6-1 \mathrm{~cm}$ (Fig. 2).

The fragment's letters are very simply cut and there is relatively little by way of serifs; the execution of some of the letters (especially the $m u$, sigma and $p i$ ) points to a date of the mid-fourth century BC. ${ }^{13}$ There are no traces of paint.

Here is the transcription of the text:

\begin{tabular}{|c|c|}
\hline & 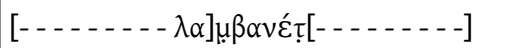 \\
\hline & 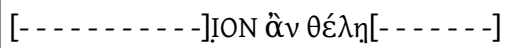 \\
\hline & 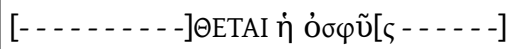 \\
\hline 4 & 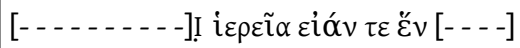 \\
\hline & 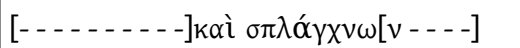 \\
\hline & 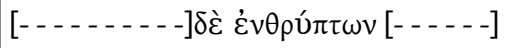 \\
\hline & 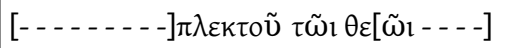 \\
\hline 8 & 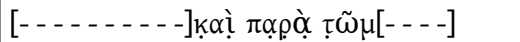 \\
\hline & 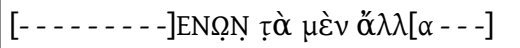 \\
\hline & [- - - - - - ] $\dot{\alpha}^{\circ} \sigma \tau \tilde{\omega} v \lambda \alpha<\mu>\beta \alpha v \varepsilon c_{[}[-$- \\
\hline & 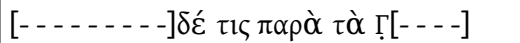 \\
\hline 12 & 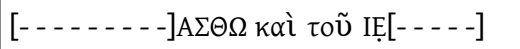 \\
\hline & 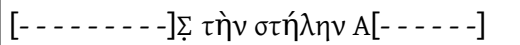 \\
\hline & 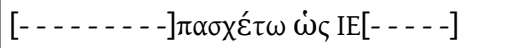 \\
\hline & 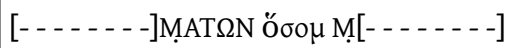 \\
\hline 16 & 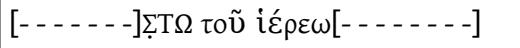 \\
\hline & [- - - - - - - -].[.]Y ع̌ \\
\hline
\end{tabular}

10.lapis $\Lambda \mathrm{A} \Lambda \mathrm{BANE}$

17.The first visible sign is a horizontal bar on the original line; of upsilon, the fork can be detected. 
It is certainly a religious text, with indications of sacrifices and offerings to a male divinity (1. 7), whose cult is administered by a male priest (1.16). Some very rare terms, like $\dot{\varepsilon} v \theta \rho \cup ́ \pi \tau \omega v$ in $1.6,{ }^{14}$ at once recall the inscription from the British Museum just discussed, I.Iasos 220. The two texts are in fact extremely similar: the text found in 2011 follows exactly the same succession of words and, taking the British Museum inscription as a guide, the preserved portion of the Iasos stele can be reconstructed as a document of 17 lines of an average length of between 27 and 32 letters per line. The reconstructed text of the new fragment matches the British Museum inscription almost perfectly and differs from Hicks' proposals at only three points (which I have underlined), two of which (1.2 and 8 of the London text) are conjectural supplements. Apart from this, the match is complete. Below is the text, supplemented on the basis of Hicks' edition. The precise layout of the column that I propose here is obviously to some degree hypothetical:

\begin{tabular}{|c|c|}
\hline & {$\left[\begin{array}{l}{[-1} \\
{[}\end{array}\right]$} \\
\hline & 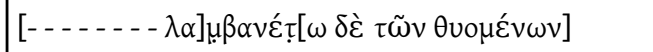 \\
\hline & 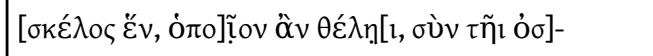 \\
\hline & 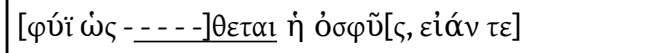 \\
\hline 4 & 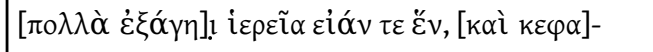 \\
\hline & 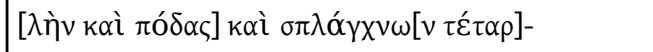 \\
\hline & 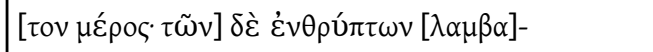 \\
\hline & 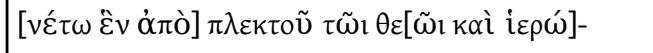 \\
\hline 8 & 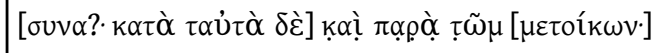 \\
\hline & 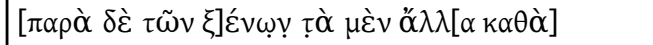 \\
\hline & 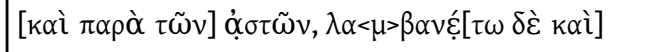 \\
\hline & 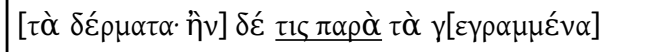 \\
\hline 12 & 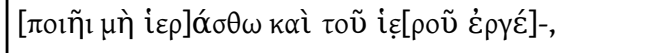 \\
\hline & 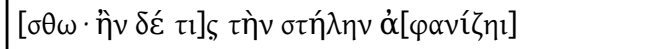 \\
\hline & 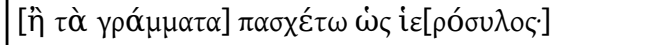 \\
\hline & 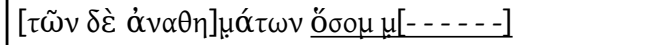 \\
\hline 16 & 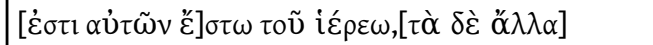 \\
\hline & 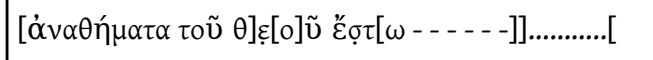 \\
\hline
\end{tabular}

\section{The constitution of a new text}

The autopsy of the stone in the British Museum and the information offered by the new fragment both provide material that may allow us to establish a new text for I.Iasos 220 .

Let us go through, in order, all of the sensitive points of the inscription, starting again from the London stone. 

leads us to propose a new supplement. Hicks, followed by all other scholars, proposed

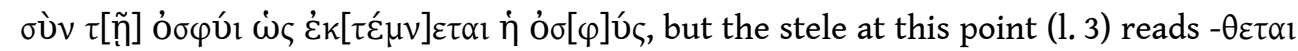
as the end of the verb. Hicks himself had qualified his own suggestion as 'doubtful'. ${ }^{15}$ The ending - $\theta \varepsilon \tau \alpha l$ can almost only be the third person singular of the middle or passive voice of the verb rí $\theta \eta \mu$ or its composite forms, and the only sensible supplement

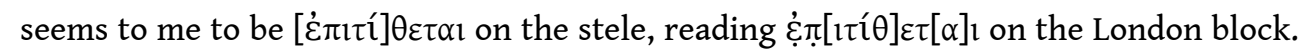
This supplement strikes me as interesting. The text is here listing the parts of the

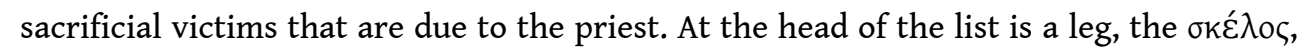
very probably one of the two hind legs in its entirety ${ }^{16}$ - only one is granted, even in cases when many animals are sacrificed. The priest can choose whichever such leg he wishes, and it is granted to him along with the ó $\sigma \varphi \tilde{v} \varsigma$. 'О $\sigma \varphi \tilde{v} \varsigma$, as has been made clear by Folkert T. van Straten and Gunnel Ekroth, ${ }^{17}$ is a term with a variable meaning: it can mean the entire pelvic girdle, including the sacral bone, it can mean only a part of it, ${ }^{18}$ or it can define the lower extremity of the spine, i.e., the sacral bone ${ }^{19}$ along with the caudal vertebrae, with or without the lumbar vertebrae. Van Straten sums up the issue on p. 128-129 as follows: "In short, one might say, the osphûs is the sacrum plus one or more parts of the skeleton connected to it". From literary sources, namely Aeschylus and some comic authors and lexicographers, we know that the ó $\sigma \varphi \tilde{v} \varsigma$ was, along with the thighs, one of the portions typically reserved for the god and burnt on the altar, ${ }^{20}$ although, as is shown by the osteological remains of the sacrifices that have been found at the shrines, and as stressed by G. Ekroth, the offering of thighs must have been more widespread and more ancient. Michael Jameson demonstrated in an experiment that the ó $\sigma \varphi \tilde{v} \varsigma$, attached to the caudal vertebrae, curls up when heated due to the contraction of the ligaments. It seems that divinatory powers were ascribed to this curling movement and that it was interpreted as a sign of the god having accepted the sacrifice. ${ }^{21}$ Perhaps it was this divinatory potential that led to the increase, apparently principally from the Classical period onwards, of the offering of the ó $\varphi \varphi \tilde{v} \varsigma$ to the god. ${ }^{22}$

indicating these bone parts, the term ó $\sigma \varphi \tilde{v} \varsigma$ could also be used to define the fleshy parts of the loins, as in regulations about sacrifices, where it is sometimes included among the portions given to the priest, as in our case. ${ }^{23}$ It is most likely an offering of this kind that is mentioned in a text from Miletus (LSAM no. 46, 2-3 and 6),

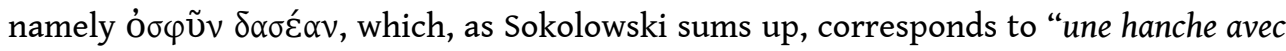
beaucoup de viande". ${ }^{24}$ The Liddell-Scott Lexicon aptly states that the adjective $\delta \alpha \sigma$ ú is "opp(osite of) $\psi \imath \lambda$ ó $\varsigma$ in all senses", and $\psi \imath \lambda$ ó $\varsigma$ is used in the inscriptions to indicate the bare ó $\sigma \varphi \tilde{v} \varsigma$, that is, the god's portion (see n. 20). The ó $\sigma \varphi \tilde{v} \varsigma$ also very likely

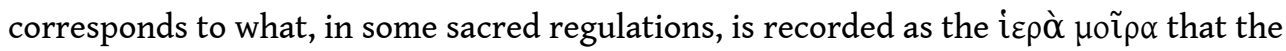
priest must take for himself. ${ }^{25}$ The connection between the part bestowed upon the god and the one offered to the priest is noteworthy. Given that the ó $\sigma \varphi \tilde{v} \varsigma$ represented a variable quantity of bone, since the sacral bone and the caudal vertebrae may or may not have been accompanied by the lumbar vertebrae and the pelvic girdle, the text specifies that the priest is to be given the part of the meat that corresponds to the ó $\sigma \varphi \tilde{v} \varsigma$ that is offered to the god. The priest had the meat of the leg and of the ó $\sigma \varphi \tilde{v} \varsigma$ as his due, to the extent that the ó $\sigma \varphi \tilde{v} \varsigma$ was offered to the god (who was evidently offered the ó $\sigma \varphi \tilde{v} \varsigma$ without its meat) ${ }^{26}$. This fact is emphasized by the use of the verb

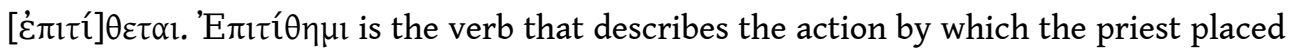
the god's portion on the altar. ${ }^{27}$ Our inscription thus expresses in a very concrete way

Kernos, 29 | 2016 
what a number of scholars have asserted: the parts assigned to the priest 'correspond'

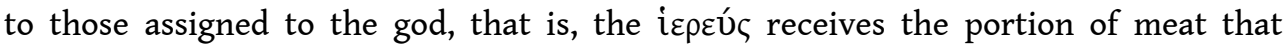
corresponds to the bones offered to the god. ${ }^{28}$

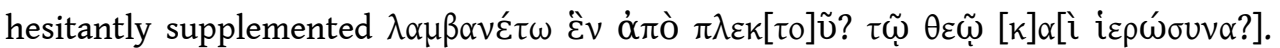

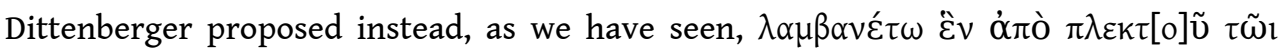

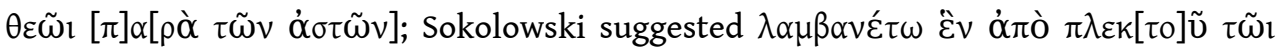

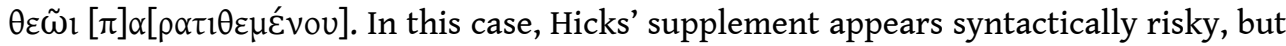
Dittenberger's proposal is also unconvincing because it does not capture the sense of the text: the syntagm $[\pi] \alpha[\rho \grave{\alpha} \tau \tilde{\omega} v \dot{\alpha} \sigma \tau \tilde{\omega} v]$, which Dittenberger inserted as an

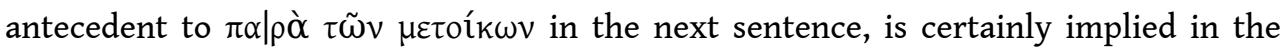
regulation, but if inserted right at this point, it would seem to refer only to the basket of cakes offered by the citizens, whereas the next sentence suggests that all the prerogatives accorded to the priest of Zeus Megistos by the citizens must also be accorded in the same manner by the metics. The supplement proposed by Sokolowski, finally, is too long. It requires 20 letters, but between $\pi \lambda \varepsilon \kappa \tau$ เõ and $\kappa \alpha \rrbracket \tau \grave{\alpha}$ in the London stone there is a space of $32 \mathrm{~cm}$, a distance that usually contains 17 letters. My

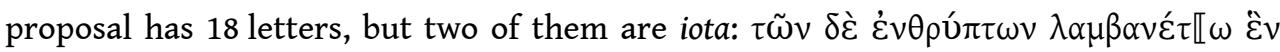

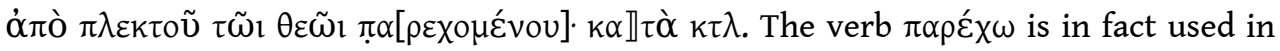
inscriptions to indicate an offering made to the god during a sacrifice; it can be either the priests or the community that performs the action of $\pi \alpha \rho \varepsilon$ xहlv: see IG II $^{2} 1365,13-$

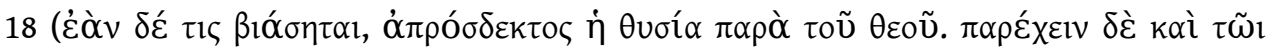

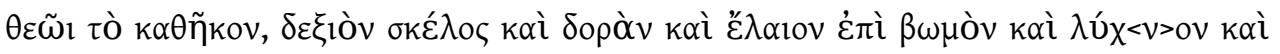

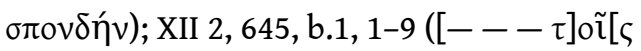

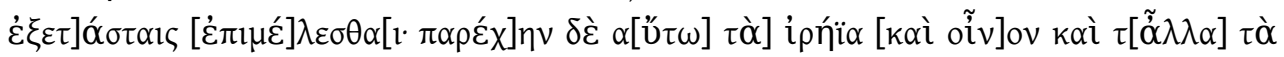

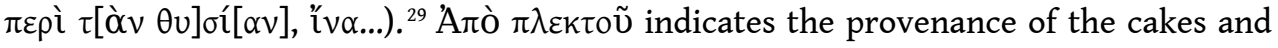
its meaning is very close to the partitive sense (cf. IG XII 6, 1, 261, 32-33). It could be understood that the priest takes a cake from each basket offered to the god (note that,

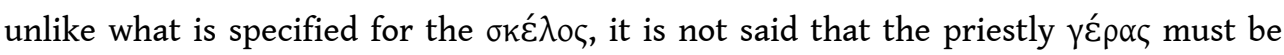
unique).

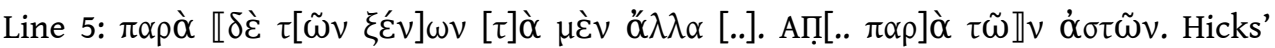

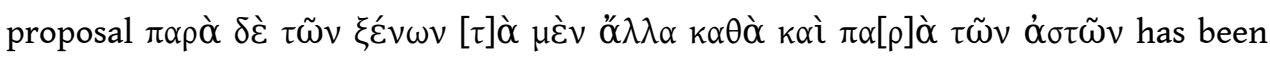
accepted by all later scholars, but our revision would suggest a small modification. Hicks' rendering gives - as stated - a very optimistic impression of the stone's condition. $\kappa \alpha \theta \dot{\alpha}$, for instance, is not certain, although possible: the first two letters are not recognizable; theta is reasonably likely (the upper part of a round letter is to be seen); only the last alpha is certain. But after this alpha, legible signs are hardly discernible; the original surface of the stone is preserved only for a short stretch. One can see very well a vertical upright stroke and a very short horizontal stroke that moves to the right from the top of the upright one, and together they seem to form a pi; there is no trace of anything lower on the vertical stroke, which is why we can safely rule out a kappa. After this sign, a portion of the stone follows which can no longer be read. On the basis of what is visible I propose the following supplement: $\pi \alpha \rho \alpha \grave{\delta} \delta \dot{\varepsilon} \tau \tilde{\omega} v$

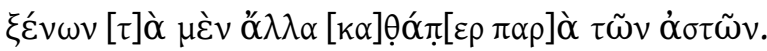

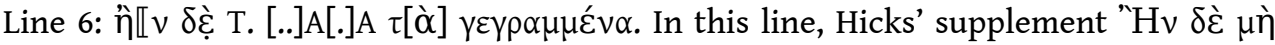

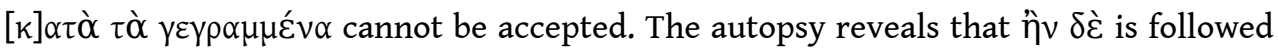


by tau (and not $m u$ ). Afterwards we find a vertical stroke followed by a lacuna that occupies the space of a couple of letters, after which a first alpha and - after an

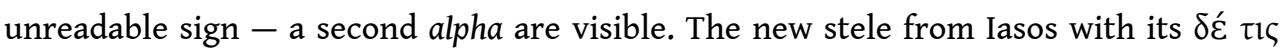
$\pi \alpha \rho \alpha \grave{~} \tau \grave{\alpha} \gamma[$ (at line 11) offers the solution, especially since the presence of a subject like $\tau \iota \zeta$ makes sense in the sentence. Since the revision of the text in London has made clear

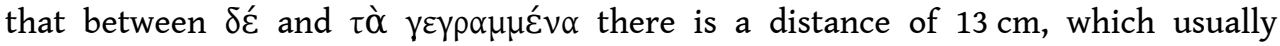
contains seven and not six letters, as in Hicks' supplement, it seems that at this point of

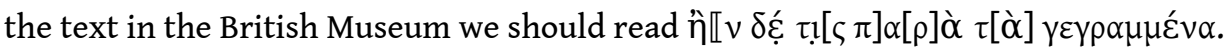

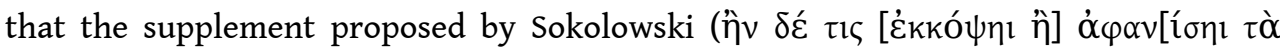

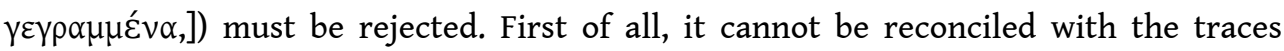
visible on the stone in the British Museum: in fact, in the long section that has been chiselled away (Fig. 3) where Sokolowski's supplement would require the final letters of $\dot{\varepsilon} \kappa \kappa o ́ \psi \eta \iota$ and $\hat{\eta}$, a triangular letter and then two vertical strokes and the remnant of a

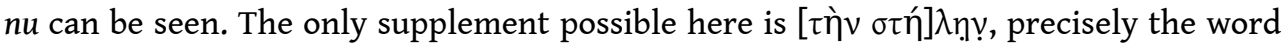
that Hicks had suggested. In this regard, it must be observed that although neither Hicks' copy of the inscription nor his textual transcription records traces of these letters - just as no traces of any of the other supplemented letters in rasura are recorded - in his notes on line 7, Hicks had already commented that "Line 7 is much defaced; my restorations however are not mere conjectures, but are suggested by what seem to be strokes of the original letters". Furthermore, the word $\sigma \tau \eta \dot{\eta} \lambda \eta v$ is now securely documented also by the new fragment from Iasos, at line 13 . The restoration I

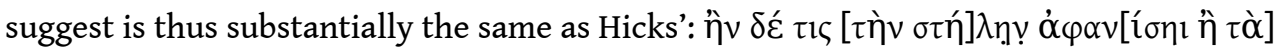
$\gamma[\rho] \alpha_{\alpha} \mu[\mu \alpha \tau \alpha] .^{30}$ This correction, in addition to confirming the homogeneity of the two texts, raises an important issue: the London inscription is in fact carved on a block and not on a stele. It seems to me that three hypotheses can be advanced to explain the lack of congruence between text and support, in increasing order of likelihood: 1) the text on the block is a copy of an inscription that was originally incised on a stele; 2) already by the start of the fourth century, texts of regulations of this kind had taken on a rather routine character: normally they were published on stelai, and consequently the expression came to be employed, inappropriately, in a text carved on a block; 3) the third possibility simply adopts and supplements this last suggestion: thanks to the

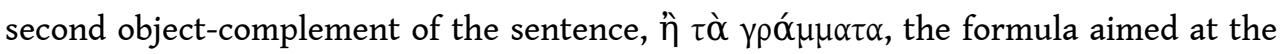
protection of the text became all-encompassing and could refer to any type of support, including texts carved on blocks. The flexibility of the formula seems to me an indication that a habit of writing regulations on various kinds of supports was consolidated at an early stage, even though stelai were certainly the preferred type, as is the case with the new fragment found in 2011.

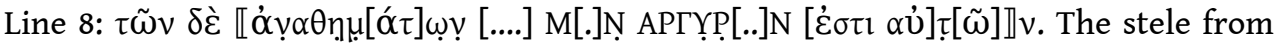
Iasos seems to necessitate another small modification to Hicks' reconstruction ( $\tau \tilde{\omega} v \delta \grave{\varepsilon}$ $\dot{\alpha} v \alpha \theta[\eta] \mu \alpha{ }^{\prime} \tau \omega \nu$ Ǒ $\sigma \alpha \mu \grave{\varepsilon} v \dot{\alpha} \rho \gamma[$ ): the new fragment presents a phrase in the singular, not the plural, in relation to the first group of $\dot{\alpha} v \alpha \theta \dot{\eta} \mu \alpha \tau \alpha$ that it distinguishes. In fact, on the stele (1. 15) we read ö $\sigma o \mu \mu[\varepsilon$ ' $v$. What follows falls in the lacuna on the stele and is in very poor condition on the block in the British Museum. Furthermore, our reexamination of the stone in London confirms, as Hicks had already written, that in this line the letters АРГ are visible. But after the gamma there is a stroke that, even though it cannot be confirmed definitively, seems likely to be an upsilon (see above in 
apparatus). In any case it could never be part of an alpha, as Sokolowski's emendation assumes; immediately after that stroke, high above the line, traces are visible of a rho. This second trace is less clear, but it suggests that in this case too, we must follow Hicks' proposal, $\dot{\alpha}$ pyúpiov. If that is accepted, the text must be prescribing that the priest receive not objects that were 'unworked and unusable', as hypothesised by Sokolowski and accepted by Gill and others, ${ }^{31}$ but rather money that was dedicated by

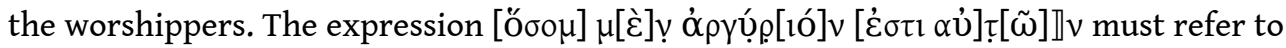
minted coinage; the god received all the rest (other metallic offerings included, of course).

Our text includes this prerogative of the priest in the category of the $\alpha v \alpha \theta \eta n \mu \alpha \tau \alpha$ : the

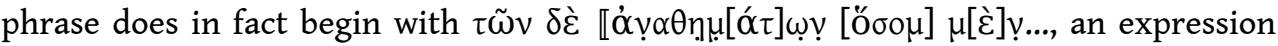
subsequently resumed by $\tau \grave{\alpha} \delta \grave{\varepsilon}$ ö $\lambda \lambda \alpha \dot{\alpha} v \alpha \theta \eta \dot{\eta} \mu \alpha \tau \llbracket \alpha$. Indeed, the gods could be offered

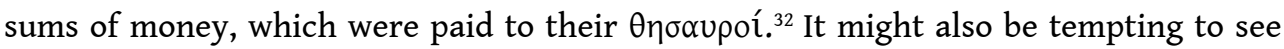
this amount as corresponding to the sums recorded in the sacrificial tariffs. Regulatory texts frequently prescribe that private persons, on the occasion of a sacrifice, must pay the priest small monetary offerings, the size of which varies according to the value of the victim offered ${ }^{33}$ In some cases it is explicitly stated that these sums are part of the $\gamma \varepsilon$ $\varepsilon \alpha$ to be paid to the priest, probably also for the purpose of meeting the expenses related to the cult..$^{34}$ The regulation under consideration does not tell us if, at this time at Iasos, those who were about to sacrifice were obliged to pay the priest a certain amount; if they were not, they could nonetheless freely choose to dedicate an offering to the priest: it was enough that they offered a coin or, in lieu of that, some other object. ${ }^{35}$ In any case, it seems that the city of Iasos considered the monetary amounts to be a kind of $\alpha$ ó $\theta \eta \eta \alpha$ that was reserved for the priest.

If we combine the information that we have gained from the new fragment with our observations at the British Museum, we can now propose for I.Iasos 220 the following new text, in which the new readings are highlighted in grey; the sections underlined are those documented in the fragment found in 2011.

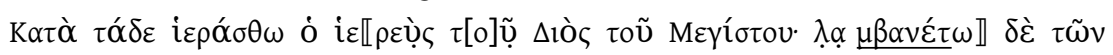
$\theta v o \mu \varepsilon ́ v \omega v v v$

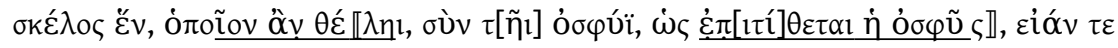
$\pi \mathrm{o} \lambda \lambda \grave{\alpha} \dot{\varepsilon} \xi \dot{\alpha}-$

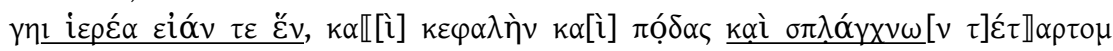
$\mu \varepsilon \dot{\varepsilon} \rho \varsigma^{-} \tau \tilde{\omega} \nu \underline{\delta \varepsilon}$

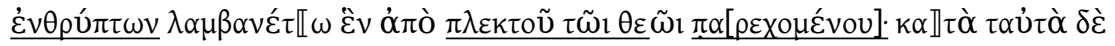

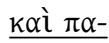

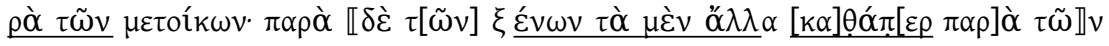
$\underline{\dot{\alpha} \sigma \tau \tilde{\omega} v, \lambda \alpha \mu \beta \alpha v \varepsilon \dot{\varepsilon}-v v}$

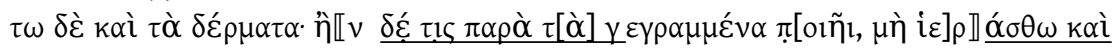
$\underline{\text { toṽ vacat }}$

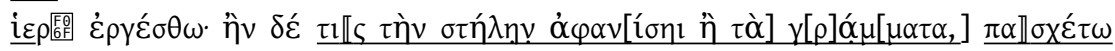
vacat

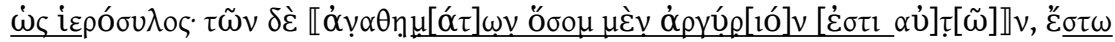

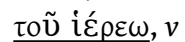

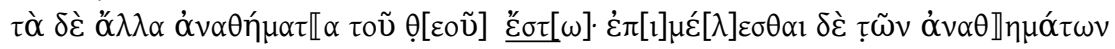
vacat

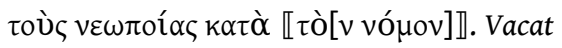

The priest of Zeus Megistos shall serve according to the following: of the sacrificed animals, whether one or many victims are led out (in procession), he shall take one leg, whichever he wishes, along with the sacrum, as this is placed on (the altar); the 
head; the feet; and a quarter of the viscera; of the cakes he shall take one from (each) basket offered to the god; (he shall take) the same also from the metics, while from the foreigners he shall take the same rewards as from the citizens, plus the skins. If the priest acts against these prescriptions, he shall no longer be priest and be barred from the sanctuary; if someone obliterates the stele or the inscription, he shall be punished as a temple-robber; among the votive offerings, the minted coinage shall be the priest's, the other votive offerings shall be property of the god. The neopoiai shall take care of the votive offerings according to the law.

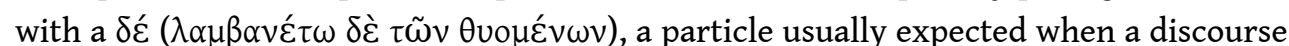
is already ongoing and not when it is beginning. Dittenberger labelled this $\delta \dot{\varepsilon}$ as a mistake. ${ }^{39}$ Furthermore, our text sets out only rules involving priestly prerogatives. It does not contain, for instance, indications about the mode of acquisition and the duration of the office of the priest. Since our inscription moreover seems to lack an explicit mention of public sacrifices and festivals, the opening $\delta \varepsilon$ could be taken as an indication that we are dealing not with a "comprehensive regulation" that sets out all the rules regarding the priest, but rather with an extract from a larger text (what Lupu defines as "specific regulations" for priests ${ }^{40}$ ), containing only the part concerning sacrifices made by private individuals. ${ }^{41}$ The aim of the regulation, however, is not as restricted as it may seem. Dittenberger rightly remarked that the reference to public

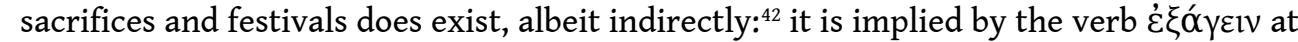
1.2-3, which alludes to a $\pi \circ \mu \pi \eta$ (probably conducted by the priest) that entailed leading out the sacrificial animals, an action that would obviously have occurred during

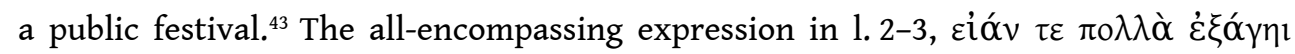

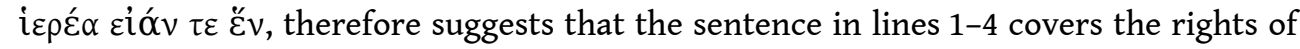
the priest in every sacrifice, both those made at public expense and those by private individuals. In addition, our document is also all-encompassing concerning the categories of free inhabitants of the town who can participate in the sacrifices to Zeus Megistos: the astoi are mentioned, along with metics and strangers (1.5). In regards to 
the initial $\delta \varepsilon$, we have at least one clear parallel. The inscription IG XII 4, 1, 356 (= LSCG

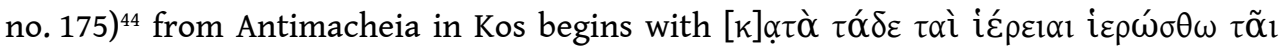

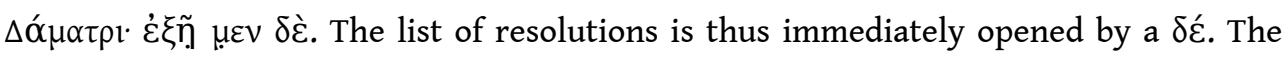
parallel urges us to think that the particle $\delta \dot{\varepsilon}$ has a different sense than expected. It must be the kind of $\delta \varepsilon$ which sometimes, as Denniston explains, ${ }^{45}$ marks the transition from the introduction of a speech to the opening of the speech proper, or introduces a disquisition predicted in advance. The heading $\kappa \alpha \tau \grave{\alpha} \tau \alpha \dot{\alpha} \delta \varepsilon$ usually introduces a set of rules, which are then listed and explained, and can be found in cases concerning leases, oaths, judgements of judicial courts or cultic regulations. ${ }^{46}$ It is therefore not necessary to think of our text as an extract. Instead, we have a document most likely concerned with a self-standing cultic regulation on the rights of the priest of Zeus Megistos. We can only speculate about the reasons why our regulation is partial and focused on the rights of the priest of Zeus Megistos on occasions of public and private sacrifices and on the $\dot{\alpha} v \alpha \theta \dot{\eta} \mu \alpha \tau \alpha$. Regardless, it is most likely not too much of an assumption to suppose that the priest of Zeus Megistos already existed at the time when the law was approved, and that there was no reason to prescribe how he had to be elected. ${ }^{47}$

One final interesting feature is present in our document worth noting; the succession of the formulae in the final part of the text. The list of the prerogatives tributed to the priest runs from 1.1 to 1.6 after which it is interrupted by the two threats against priests who do not abide by the rules and against those who may deface the text. After these supposedly terminal norms, the document returns to the priestly prerogatives, now considering the $\dot{\alpha} v \alpha \theta \eta \dot{\eta} \mu \alpha \tau \alpha$. Why this peculiar sequence? ${ }^{48}$ Two hypothesis can be proposed. One could assume that the addition of 1. 8-10 concerning the $\alpha \dot{\alpha} \alpha \theta \eta \dot{\eta} \mu \alpha \tau \alpha$ is the result of an amendment to an initial law proposal that had not provided this kind of indication. ${ }^{49}$ Another possibility is that the actual text was conceived of by a single person or political body, but its structure reflects a stratified documentary model. A norm concerning the $\dot{\alpha} v \alpha \theta \dot{\eta} \mu \alpha \tau \alpha$ could have been added to an older core centered on a regulation about traditional prerogatives and already completed by the clause protecting the written text. The reference to monetary offerings could be an indication that the rule about the $\dot{\alpha} v \alpha \theta \eta \dot{\eta} \mu \alpha \tau \alpha$ was, in reality, a later addition. Unfortunately, the history of the text and the logic underlying its construction will likely always remain elusive.

Finally, what about the inscription on the newly discovered stele? First of all, the match between its text and the one preserved in the British Museum, especially in terms of the perfect coincidence of the $ү \varepsilon ́ p \alpha$ that they prescribe, strongly suggests that we are dealing with the same regulation for the same priesthood. I am inclined to rule out the possibility that this is a vónoৎ that has been applied in exactly the same way to two different priesthoods. If we accept that both texts regulate the priesthood of Zeus Megistos, and we also consider the perfect match, even in the sequence of the formulae in the two texts, it seems necessary to conclude that the stele is an exact copy of the vó $\mu$ o inscribed on the London block. This is then its final restitution:

\begin{tabular}{|c|}
\hline 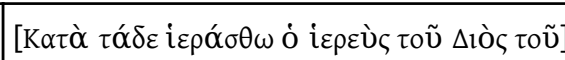 \\
\hline 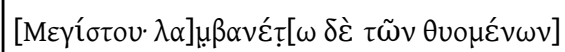 \\
\hline 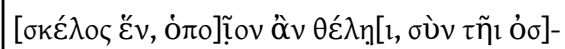 \\
\hline
\end{tabular}




\begin{tabular}{|c|c|}
\hline & 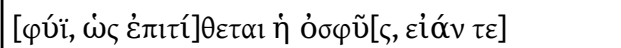 \\
\hline \multirow[t]{4}{*}{4} & 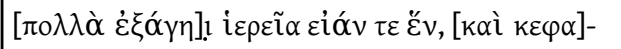 \\
\hline & 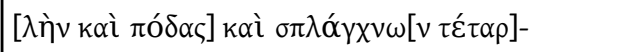 \\
\hline & {$[\tau o v \mu \varepsilon \dot{\varepsilon} \rho \circ \cdot \tau \tilde{\omega} v] \delta \dot{\varepsilon} \varepsilon \dot{\varepsilon} v \theta \rho \dot{\pi} \pi \tau \omega \nu[\lambda \alpha \mu \beta \alpha]-$} \\
\hline & 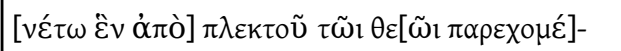 \\
\hline \multirow[t]{4}{*}{8} & 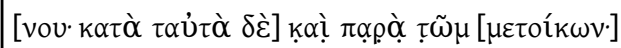 \\
\hline & 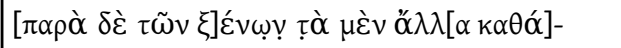 \\
\hline & 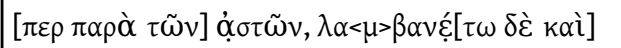 \\
\hline & 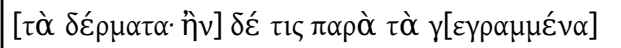 \\
\hline \multirow[t]{4}{*}{12} & 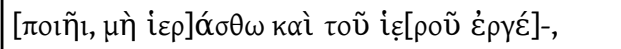 \\
\hline & 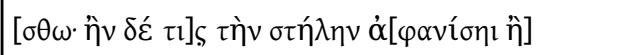 \\
\hline & 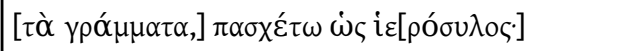 \\
\hline & 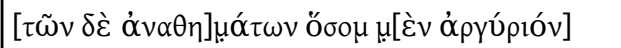 \\
\hline \multirow[t]{4}{*}{16} & 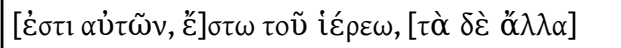 \\
\hline & 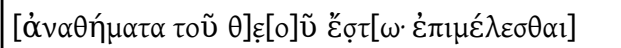 \\
\hline & 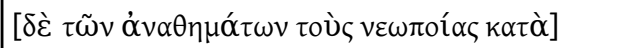 \\
\hline & 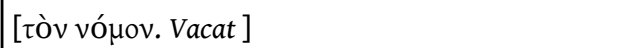 \\
\hline
\end{tabular}

The reason for publishing this law a second time in exactly the same way remains another obscure feature of this document. It is well known that in Kos we frequently find two, or even more, copies of the same priestly regulation. ${ }^{50}$ This occurs, however, in the case of priesthood sales, since every sale (with its own date and cost) can justify the new publication of the contract. But in case of a law, there must have been other reasons, which we are not able to grasp..$^{51}$

Be this as it may, the strength of the regulation had lost its force by Byzantine times. It was at this time that someone found the text on the block still intact and decided to deface the inscription. The threatening injunction was now ineffective, and its

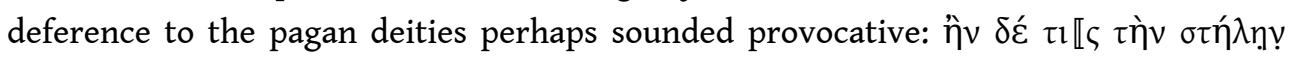

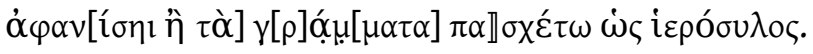

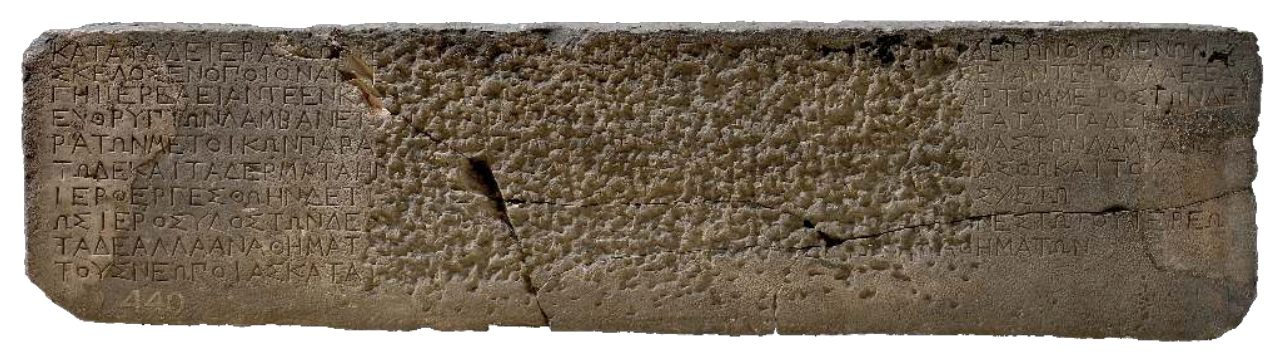

FIg. 1 


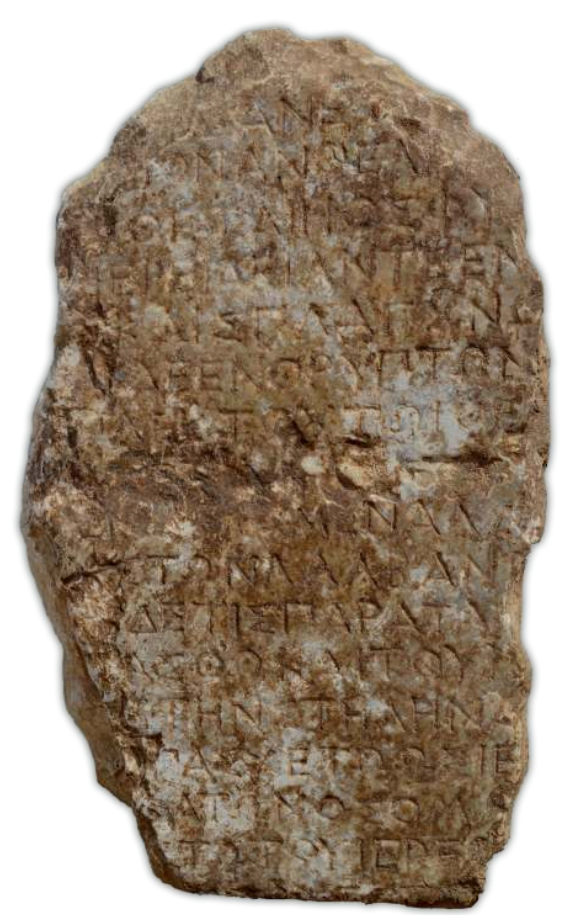

FIg. 2

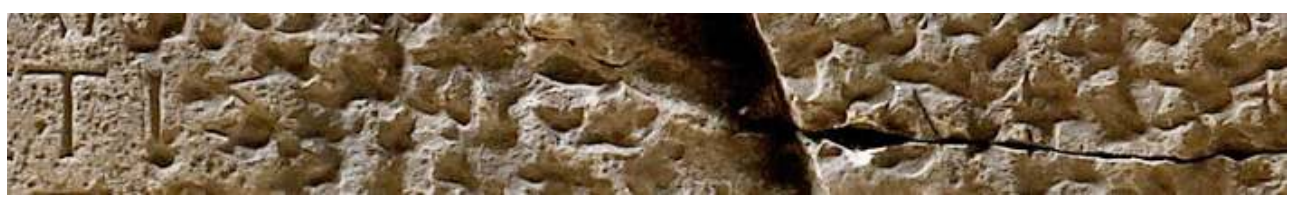

Fig. 3

BIBLIOGRAPHY

\section{Abbreviations}

I.Erythrai

H. ENGELMANN, R. MERKELBACH, Die Inschriften von Erythrai und Klazomenai I-II, Bonn, 1972-1973

(Inschriften griechischer Städte aus Kleinasien, 1).

I.Iasos

W. BLÜMEL, Die Inschriften von Iasos I-II, Bonn, 1985 (Inschriften griechischer Städte aus Kleinasien, 28). I.Mylasa 
W. BLÜMEL, Die Inschriften von Mylasa I-II, Bonn, 1987-1988 (Inschriften griechischer Städte aus Kleinasien, 34).

I.Magnesia

O. KERN, Die Inschriften von Magnesia am Maeander, Berlin, 1900.

LSAM

Fr. sокоLоwsкI, Lois sacrées de l'Asie Mineure, Paris, 1955.

LSCG

Fr. SокоLоWSKI, Lois sacrées des cités grecques, Paris, 1969.

LSS

Fr. SокоLOWSKI, Lois sacrées des cités grecques. Supplément, Paris, 1962.

MCCABE, Iasos

D.F. McCabe, Iasos Inscriptions. Texts and List, The Princeton Project on the Inscriptions of Anatolia, The Institute for Advanced Study, Princeton (Packard Humanities Institute CD \#6, 1991).

BECHTEL (1905): F. BECHTEL, Sammlung der griechischen Dialekt-Inschriften, III.2, Göttingen, 1905.

BERTI (2012): F. BERTI, “Nuovi dati per le mura urbane di Iasos”, in B. SOĞUT (ed.) Stratonikeia'dan Lagina'ya. Ahmet Adil Tirpan Armağanı. From Stratonikeia to Lagina. Festschrift in Honour of Ahmet Adil Turpan, Istanbul, 2012, p. 101-113.

CARBON (2013): J.-M. CARBON, "Ritual Problems: Offering and Sacrificing”, Kernos 26 (2013), p. 381388.

CARBON - PIRENNE-DELFORGE (2012): J.-M. CARBON, V. PIRENNE-DELFORGE, “Beyond Greek ‘Sacred Laws' ”, Kernos 25 (2012), p. 163-182.

COHEN (1983): D. COHEN, Theft in Athenian Law, München, 1983 (Münchener Beiträge zur Papyrusforschung und Antiken Rechtsgeschichte, 74).

CROWTHER (1989): Ch. V. CROWTHER, “Iasos in the Early Second Century BC: A Note on OGIS 137", BICS 36 (1989), p. 136-138.

CROWTHER (1994): Ch. V. CROWTHER, “Lord Dufferin's Grand Tour and the collection of Greek inscriptions at Clandeboye", JAC 9 (1994), p. 14-32.

DENNISTON (1954²): J.D. DENNISTON, The Greek Particles, Oxford, $1954^{2}$.

DIGNAS (2002): B. DIGNAS, Economy of the Sacred in Hellenistic and Roman Asia Minor, Oxford, 2002.

Dimitrova (2008): N. DIMITROVA, "Priestly prerogatives and hiera moira”, in A. MATTHAIOU, I. POLYNSKAIA (eds.), Mikros Hieromnemon, Athens, 2008, p. 251-257.

DUNCAN (1961): U.K. DUNCAN, "Notes on lettering by some attic masons in the sixth and fifth centuries BC", ABSA 56 (1961), p. 179-188.

DURAND (1989): J.-L. DURAND, “Greek animals: Toward a Topology of Edible Bodies”, in M. DETIENNE, J.-P. VERNANT (eds.), The Cuisine of Sacrifice among the Greeks, (engl. transl. by P. Wissing of La cuisine du sacrifice en pays grecque, Paris, 1979), Chicago, 1989, p. 87-109.

EKROTH (2008): G. ЕКROTH, "Meat, man and god. On the division of the animal victim at Greek sacrifices", in A. MATTHAIOU, I. POLYNSKAIA (eds.), Mikros Hieromnemon, Athens, 2008, p. 259-290. 
EKROTH (2009): G. ЕКROTH, “Thighs or tails? The osteological evidence as a source for Greek ritual norms", in P. BRULÉ (éd.), La norme en matière religieuse en Grèce ancienne, Liège, 2009 (Kernos Suppl. 21), p. 125-151.

EKROTH (2013): G. EKROTH, “Forelegs in Greek cult", in A.-L. SCHALLIN (ed.), Perspectives on Ancient Greece. Papers in celebration of the $60^{\text {th }}$ anniversary of the Swedish Institute at Athens, Stockhom, 2013, p. 113-134.

FABIANI (2013): R. FABIANI, “Iasos between Mausolus and Athens", in P. BRUN, L. CAVALIER et al. (eds.), Euploia. La Lycie et la Carie antiques. Dynamiques des territoires, échanges et identités. Actes du colloque de Bordeaux, 5, 6 et 7 novembre 2009, Bordeaux, 2013, p. 317-330 (Ausonius Mémoires, 34).

FABIANI (2015): R. FABIANI, I decreti onorari di Iasos. Cronologia e storia, München, 2015 (Vestigia, 66). FABIANI - NAFISSI (2013): R. FABIANI, M. NAFISSI, "La pubblicazione dei decreti a Iasos: cronologia e topografia", in D. BALDONI, F. BERTI, M. GIUMAN (eds.), Iasos e il suo territorio. Atti del convegno internazionale per i cinquanta anni della Missione Archeologica Italiana. Istanbul, 26-28 febbraio 2011, Roma, 2013, p. 37-60.

FRANCO (1994): C. FRANCO, "Le mura di Iasos. Riflessioni tra archeologia e storia", in Fortifications et défense du territoire en Asie Mineure occidentale et méridionale. Table ronde CNRS, Istanbul mai 1993, REA 96 (1994), p. 173-184.

FRANCO (2004): C. FRANCO, "Iasos ellenistica tra politica e cultura”, in M. FANO SANTI (ed.), Studi di archeologia in onore di Gustavo Traversari I, Roma, 2004, p. 383-395.

GEORGOUDI (1998): S. GEORGOUDI, "Sacrifices dans le monde grec: de la cité aux particuliers. Quelques remarques”, Ktema 23 (1998), p. 325-334.

GEORGOUDI (2010): S. GEORGOUDI, “Comment régler les theia pragmata. Pour une étude de ce qu'on appelle « lois sacrées »", Metis 8 (2010), p. 39-54.

GILL (1974): D. GILL, “Trapezomata: a neglected aspect of Greek sacrifice”, HThR 67 (1974), p. $117-$ 137.

GILL (1991): D. GILL, Greek Cult tables, New York and London, 1991.

HAMILTON (2000): R. HAMILTON, Treasure map. A guide to the Delian inventories, Ann Arbor, 2000.

HARRIS (1995): D. HARRIS, The treasures of the Parthenon and Erechtheion, Oxford, 1995.

HARTER-UIBOPUU (2014): K. HARTER-UIBOPUU, “Tote soll man ruhen lassen... Verbote und Strafen zur Sicherung von Gräbern am Beispiel von Inschriften aus Ephesos”, in J. FISCHER (ed.), Der Beitrag Kleinasiens zur Kultur- und Geistesgeschichte der griechisch-römischen Antike. Akten des Internationalen Kolloquiums, Wien, 03-05 November 2010, Wien, 2014 (Österreichische Akademie der Wissenschaften, Philosophisch-Historische Klasse, Denkschriften, 469), p. 157-180.

HOFFMANN (1898): O. HOFFMANN, Die griechischen Dialekte in ihrem historischen Zusammenhange mit den wichtigsten ihrer Quellen, III, Göttingen, 1898.

LAQUEUR (1927): R. LAQUEUR, Epigraphische Untersuchungen zu den griechischen Volksbeschlüssen, Leipzig/Berlin, 1927.

LE GUEN-POLLET (1991a): B. LE GUEN-POLLET, La vie religieuse dans le monde grec du $v^{e}$ au $I I I^{e}$ siècle avant notre ère. Choix de documents épigraphiques traduits et commentés, Toulouse, 1991.

LE GUEN-POLLET (1991b): B. LE GUEN-POLLET, “Espace sacrificiel et corps des bêtes immolées. Remarques sur le vocabulaire designant la part du prêtre dans la Grèce antique, de l'époque classique à l'époque imperiale", in R. ÉTIENNE, M.-Th. LE DINAHET (eds.), L'espace sacrificiel dans les 
civilisations méditerranéennes de l'antiquité. Actes du colloque tenu à la Maison de l'Orient, Lyon, 4-7 juin 1988, Paris, 1991, p. 13-23.

LIPINSKI (1975): E. LIPINSKI, Studies in Aramaic inscriptions and onomastics, Leuven, 1975.

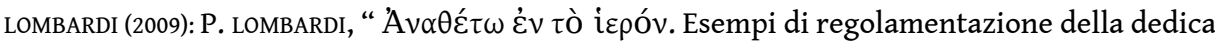
votiva nel mondo greco", in J. BODEL, M. KAJAVA (eds.), Dediche Sacre nel mondo greco-romano. Diffusione, funzioni, tipologie / Religious Dedications in the Greco-Roman World. Distribution, Typology, Use. Institutum Romanum Finlandiae, American Academy in Rome, 19-20 aprile 2006, Roma, 2009 (Acta Instituti Romani Finlandiae, 35), p. 95-126.

LOMBARDI (2010): P. LOMBARDI, “La 'colpa' di Gadatas. Osservazioni lessicali sulla 'Lettera di Dario a Gadatas' ”, IncidAntico 8 (2010), p. 163-195.

LUPU (2003): E. LUPU, "Sacrifice at the Amphiareion and a Fragmentary Sacred Law from Oropos", Hesperia 72 (2003), p. 321-340.

LUPU (2009²): E. LUPU, Greek Sacred Law. A Collection of New Documents $\left(N G S L^{2}\right) .2^{\text {nd }}$ Edition with a Postscript, Leiden/Boston, 2009 (Religions in the Graeco-Roman World, 152).

MA (2000): J. MA, Antiochos III and the Cities of Western Asia Minor, Oxford, 2000.

MADDOLI (1995): G. MADDOLI, "Vicende e prospettive delle iscrizioni di Iasos", in Iasos di Caria. Un contributo ferrarese alla archeologia microasiatica. Progetti e lavori di restauro, Ferrara, 1995, p. 65-81. MADDOLI (2007): G. MADDOLI (con la collaborazione di R. FABIANI e M. NAFISSI), Epigrafi di Iasos. Nuovi supplementi, I, PP 62 (2007), p. 193-372.

MADDOLI (2010): G. MADDOLI, “Memoria e riscoperta”, in F. BERTI, R. FABIANI, Z. KIZILTAN, M. NAFISSI (eds.), Marmi erranti. I marmi di Iasos presso i Musei Archeologici di Istanbul. Gezgin Taşlar. Istanbul Arkeolojy Müzeleri'ndeki Iasos Mermerleri. Wandering Marbles. Marbles of Iasos at the Istanbul Archaeological Museums (Istanbul Arkeoloji Müzeleri, 7.12.2010 - 4.7.2011), Istanbul, 2010, p. 154-156 (English).

MADDOLI (2015): G. MADDOLI, “Iasos: vendita del sacerdozio della Madre degli Dei”, in Epigrafi di Iasos. Nuovi supplementi, II. In memoria di Giovanni Pugliese Carratelli, SCO 61.2 (2015), p. 101-118.

MASTURZO (2012): N. MASTURZO, Architettura ed epigrafia a Iasos. Linee per la ricomposizione dei contesti monumentali pubblici, Tesi di Dottorato Università di Perugia, 2012.

MCLEAN (2002): B.H. MCLEAN, An Introduction to Greek Epigraphy of the Hellenistic and Roman Periods from Alexander the Great down to the Reign of Constantine (323 BC-AD 337), Ann Arbor, 2002.

MEADows (1996): A. MEADows, "Four Rhodian Decrees. Rhodes, Iasos and Philip V", Chiron 26 (1996), p. 251-266.

MICHEL (1900): Ch. MICHEL, Recueil d'inscriptions grecques, Bruxelles, 1900.

MORTON (2015): J. MORTON, “The Experience of Greek Sacrifice: Investigating Fat-Wrapped Thigh Bones", in M.M. MILEs (ed.), Autopsy in Athens. Recent Archaeological Research on Athens and Attica, Oxford, 2015, p. 66-75.

NAFISSI (2015): M. NAFISSI, "Una dedica a Basìleia da Iasos e il duplice culto della Madre degli Dei e della Madre Frigia", in Epigrafi di Iasos. Nuovi supplementi, II. In memoria di Giovanni Pugliese Carratelli, SCO 61.2 (2015), p. 119-136.

NEWTON - HICKS (1890): Ch. Th. NEWTON, E.L. HICKS, Collection of Ancient Greek Inscriptions in the British Museum (GIBM). Priene, Iasos and Ephesos III, Oxford, 1890. 
PARKER (1983): R. PARKER, Miasma. Pollution and Purificaton in early Greek Religion, Oxford, 1983.

PARKER (2004): R. PARKER, “What are Sacred Laws?”, in E.M. HARRIS, L. RUBINSTEIN (eds.), The Law and the Courts in Ancient Greece, London, 2004, p. 57-70.

PARKER (2005): R. PARKER, “Law and Religion”, in M. GAGARIN, D. COHEN (eds.), The Cambridge Companion to Ancient Greek Law, Cambridge, 2005, p. 61-81.

PATERA (2012): I. PATERA, Offrir en Grèce ancienne. Gestes et contextes, Stuttgart, 2012 (Potsdamer Altertumswissenschaftliche Beiträge, 41).

PAUL (2013): S. PAUL, Cultes et sanctuaires de l'île de Cos, Liège, 2013 (Kernos, suppl. 28).

PETZL - SCHWERTHEIM (2006): G. PETZL, E. SCHWERTHEIM, Hadrian und die dionysischen Künstler. Drei in Alexandria Troas neugefundene Briefe des Kaisers an die Künstler-Vereinigung, Bonn, 2006 (Asia Minor Studien, 58).

PIMOUGUET-PÉDARROS (2000): I. PIMOUGUET-PÉDARROS, Archéologie de la défense. Histoire des fortifications antiques de Carie (époques classique et hellénistique), Paris, 2000.

PIRENNE-DELFORGE (2006): V. PIRENNE-DELFORge, s.v. "Personnel de culte: monde grec", ThesCRA V (2005), p. 1-31.

DE PONTBRIANT (2010): A. DE PONTBRIAND, “A Greek Inscription from Area 13c”, in C. VON PILGRIM, R. Colman et al., "The Town of Syene. Report on the $7^{\text {th }}$ Season in Aswan", MDAI(K), 66 (2010), p. 205211.

PUGliese CARRATelli (1985): G. PUglieSE CARRATElli, “Cari in Iasos”, RAL 40 (1985) [1986], p. 149-155. RHODES - LEWIS (1997): P.J. RHODES, D.M. LEWIS, The Decrees of the Greek States, Oxford, 1997.

ROBERT (1955): L. ROBERT, “Épigraphie et paléographie”, CRAI 99.2 (1955), p. 195-222.

ROBERT (1971): J. and L. ROBERT, “Bulletin épigraphique”, REG 84 (1971), no. 621, p. 507-508.

ROBERT (1974): J. and L. ROBERT, “Bulletin épigraphique”, REG 87 (1974), no. 692, p. 326-327.

ROMAGNOLI (2012): G. ROMAGNOLI “Scavi nella stoà settentrionale dell'agorà di Iasos. Campagna 2011", Bollettino Associazione Iasos di Caria 18 (2012), p. 10-14.

RUTHERFORD (2007): I. RUTHERFORD, “Theoria and Theatre at Samothrace: the Dardanos by Dymas of Iasos", in P. WILson (ed.), The Greek Theatre and Festivals. Documentary Studies, Oxford, 2007 (Oxford Studies in Ancient Documents), p. 279-293.

RUTHERFORD (2013): I. RUTHERFORD, State Pilgrims and Sacred Observers in Ancient Greece. A Study of Theoria and Theoroi, Cambridge, 2013.

SASSU (2014): R. SASSU, “Alcune osservazioni sui chremata preservati nei santuari greci di epoca arcaica e classica", Thiasos 3.1 (2014), p. 3-15.

SCHIPPERHEIJN (2013): M.P. SCHIPPERHEIJN, s.v. “Hierosylia”, EAH VI (2013), p. 3215.

SCHWENK (1985): C.J. SCHWENK, Athens in the Age of Alexander. The Dated Laws and Decrees of "The Lycourgan Era" 338-322 BC, Chicago, 1985.

SHAW - SHAW (2000): J.W. SHAW, M.C. SHAW (eds.), Kommos IV 1-2, Princeton - Oxford, 2000.

SOKоLOWSKI (1954): F. SOKоLоWSKI, “Fees and taxes in the Greek cults”, HThR 47.3 (1954), p. 153-164.

STRUBBE (1997): J. STRUBBE, APAI EПITYMBIOI. Imprecations against Desecrators of the grave in the Greek epitaphs of Asia Minor. A Catalogue, Bonn, 1997 (Inschriften griechischer Städte aus Kleinasien, 52). 
THOMAS (1995): R. THOMAS, “Written in Stone? Liberty, Equality, Orality and the Codification of Law”, BICS 40 (1995), p. 59-74.

THOMAS (2005): R. THOMAS, “Writing, Law, and Written Law”, in M. GAGARIN, D. COHEN (eds.), The Cambridge Companion to Ancient Greek Law, Cambridge, 2005, p. 41-60.

THREATte (1980): L. THREATTE, The Grammar of Attic inscriptions. I. Phonology, Berlin and New York, 1980.

TRAMPEDACH (2005): K. TRAMPEDACH, “Hierosylia. Gewalt in Heiligtümern”, in S. MORAW, G. FISCHER (eds.), Die andere Seite der griechischen Klassik. Gewalt im 5. und 4. Jahrhundert v. Chr., Stuttgart, 2005, p. $143-165$.

VAN STRATEN (1995): F.T. VAN STRATEN, Hierà kalà. Images of Animal Sacrifice in Archaic \& Classical Greece, Leiden, 1995 (Religions in the Graeco-Roman World, 127).

VISCOGLIOSI (2009): A. VISCOGLIOSI, "Il 'Castello di terraferma' a Iasos", Bollettino Associazione Iasos di Caria 15 (2009), p. 6-13.

WAYWELL (1996): G.B. WAYWELL, “The Scylla monument from Bargylia”, Antike Plastik 25 (1996), 75119.

WIEMER - KAH (2011): H.U. WIEMER, D. KAH, "Die Phrygische Mutter im hellenistischen Priene: eine neue Diagraphe und verwandte Texte", EA 44 (2011), p. 1-54.

WÖRRLE (1991): M. WÖRRLE, “Epigraphische Forschungen zur Geschichte Lykiens. IV. Drei griechische Inschriften aus Limyra”, Chiron 21 (1991), p. 203-239.

\section{NOTES}

1. The priests of the god, unique among the hiereis, are found in the long list of officials which the polis called to supervise and ensure the operation of confiscating the goods of those Iasians who had conspired against Mausolus (I.Iasos 1, 14-18). To Zeus Megistos was dedicated a temenos, as mentioned in I.Iasos 233 and 234, two horoi, the first of which was engraved on the $4^{\text {th }}$-century wall of the city, probably dating back to the Hekatomnid period [concerning this wall see FRANCO (1994), esp. p. 177-179; PIMOUGUET-PÉDARROS (2000), p. 289-292; BERTI (2012); MASTURZO (2012)], immediately outside the so-called East Gate. Zeus Megistos is still mentioned in I.Iasos 219, 1-2, an inscription probably from the end of the $3^{\text {rd }}$ century BC.

2. .NEWTON - HICKS (1890), no. 440, p. 54-55.

3. .In addition to the one under examination, which we are told comes from a "Byzantine building" (see below), the other four stones are: 1) One of the doorjambs of the western gate of the bouleuterion, on which are engraved the decrees of the Rhodians (GIBM $441=$ I.Iasos 150), attesting to their mediation on behalf of the Iasians at the court of Philip V of Macedon at a time when Iasos was suffering from attacks by Podilos, 220-214 BC (an emissary of Olympichos, who in turn was a subordinate of the Macedonian King; see MEADOws 1996); on the stone, its characteristics, and its provenance see MASTURzo (2012), p. 60-77, 147-156. 2) The block bearing a decree of the Iasians in honour of Antiochus III, queen Laodike, and their children (GIBM 442), erroneously considered by ROBERT (1971) as a fragment of the stele bearing another famous Iasian decree in favour of the same sovereign: on the basis of this identification W. Blümel has inserted GIBM 442 at lines 51-62 of I.Iasos 4; the identification has been denied, however, by CROWTHER (1989); see also MA (2000), no. 28, p. 336-337. Hicks informs us that the stone was "taken from the wall of a bath of the Byzantine period": the indication is very vague, but I wonder if it could come 
from the area of the so-called "Castello dell'istmo" or "Castello di terraferma", where thermal buildings have been identified (viscogliosi [2009], p. 6-8). 3) The cornice of the base of a niche, on which is engraved a dedication to Homonoia and the Demos by the five epimeletai and the architect who had been charged by the polis of Iasos to take care of the restoration of the bouleuterion and the archeion (GIBM $443=$ I.Iasos 252, end of the $3^{\text {rd }}$ century BC: FABIANI [2015], p. 266-267); Hicks does not provide information about its provenance; MASTURZO (2012), p. 163-167, after examining the stone, suggests that it could come from the theatre, because of the similarity with a cornice found there. Because of the content of the dedication and the provenance of GIBM 442, I think it difficult to rule out the possibility that it may come from the bouleterion [or from the archeion: that the two monuments were close to each other is very likely: see FABIANI - NAFISSI (2013), p. 4551]. 4) The stele bearing two decrees of Samothrace in honour of the Iasian poet Dymas son of Antipatros (GIBM $444=$ I.Iasos 153, early $2^{\text {nd }}$ century BC), author of a tragedy entitled Dardanos; on Dymas, see FRANCO (2004), p. 393-394, RUTHERFORD (2007) and RUTHERFORD (2013), p. 282-284, 400402; we know nothing about the exact location of the discovery of the stele: in lines 33-34 of I.Iasos 153, the Iasians are asked to allow the second of the two decrees to be engraved in a sanctuary, but it is not specified which one; Iasian habit would suggest that the stele was erected either in the shrine of Zeus (and Hera) or in that of Artemis Astiàs [see FABIANI - NAFISSI (2013), p. 54-58]; but it is virtually certain that the stele was found in a context of reuse.

4. The journey of William Beauclerk, tenth Duke of St. Albans, on board of the Xantha in January of 1872, is indeed poorly known, as far as I can tell. During the same trip, the Duke also visited Bargylia, where he recovered some fragments of the Scylla monument, which were also donated to the British Museum: see WAYwELL (1996), p. 79-80; among other things, he also donated to the BM findings from the Carian Chersonesus and Loryma. We know of other similar cases of removal of stones from Iasos: see MADDOLI (1995), p. 69-71; (2010). A better studied episode is one in which Lord Dufferin was the protagonist. During his stay (1859), he carried off a big pillar on which a large number of choregic texts was engraved (I.Iasos 160-166; 170-177; 204-208) and which is still kept on his family manor in Ireland, the Clandeboye House: see CROWTHER (1994).

5. .In general see ROBERT (1955), p. 211, n. 2; DUNCAN (1961), p. 180; particularly ROBERT (1974); MCLEAN (2002), p. 13. To the long list in ROBERT (1974) - where a general reference to Lycian texts is found: bichromy is to be observed with a certain frequency on some Lycian rock-tombs, where signs in blue and red or in green and red alternate; one of these is a bilingual Greek-Aramaic inscription engraved on a rock-cut tomb from Limyra [Fellows (1841), p. 468, no. 1 (cf. p. 209 too) = CIS II 1, no. 109; see also LIPINSKI (1975), p. 162-164]; the Aramaic inscription is in blue, the Greek in red; other tombs in Limyra have bicolor Lycian inscriptions as well (FELLows, ibidem, p. 468, no. 2, 4), one case is reported also in Myra (ibidem, no. 13) -, today some others can be added. At Vergina there is a funerary stele of late $4^{\text {th }}$ century $B C$ where black and red letters alternate (SEG 35, 771 and 779); at Kommos, in Crete, on a late $2^{\text {nd }}-$ early $1^{\text {st }}$ century BC epitaph, at 1.1 red letters alternate with black ones, while at 1.2-3 red letters alternate with blue ones [SHAW - SHAW (2000), no. 77, p. 126-127, pl. 2.13]; at Syene, in Egypt, in a dedication of a banquet hall by a cultic association (probably of the early $3^{\text {rd }}$ century $\mathrm{BC}$ ) the first line, containing the dedication, is written in blue; then names follow on several lines, some of them in blue, some in red (DE PONTBRIAND 2010, p. 205-206); the stele of Alexandria Troas, on which three letters of the Emperor Hadrian to the Technitai of Dionysos are engraved (133/134 AD), presents lines written in red and some currently not colored, perhaps due the loss of other (blue? black?) less resistant colors: PETZL - SCHWERTHEIM (2006), p. 7.

6. See next footnote.

7. .Although it is intact, the block is damaged on the front by many fractures, the deepest of which runs obliquely from left to right. The back, which on its upper part and towards the short sides is roughly shaped, shows traces of a chisel point on the central and lower part. The left and 
the top sides have been smoothed with the chisel point and towards the front display a thin (ca. $1.2 \mathrm{~cm}$ ) band, refined with a flathead scalpel; this band, which in any case is quite rough, is slightly lower in comparison to the rest of the surface. The right side, although irregularly chipped, presents a margin that is almost straight and more or less orthogonal to the other sides. Measures of the block: width $129.5 \mathrm{~cm}$; height $31 \mathrm{~cm}$; maximum preserved thickness $18.5 \mathrm{~cm}$; height of the letters $1.8 \mathrm{~cm}$ (omicron, theta: $1.2 \mathrm{~cm}$; omega: $1.4 \mathrm{~cm}$ ). The line spacing is irregular and varies between $0.5-0.7 \mathrm{~cm}$. To the left, an uninscribed rim of $3 \mathrm{~cm}$; at the bottom, one of ca. $5 \mathrm{~cm}$.

8. .Chipping starts at $36 \mathrm{~cm}$ from the left edge and ends ca. $30.5 \mathrm{~cm}$ from the right edge.

9. .Hicks, in NEWTON - HICKS (1890), p. 54. On the autopsy of the stone, which I conducted together with Nicolò Masturzo and Massimo Nafissi in March 2010, see below.

10. The closest Iasian parallel is PUGLIESE CARRATELLI 1985, II b (= SEG 36, 982 B) - see FABIANI (2015), p. 143 and 147 (script) and p. 252-253 (dating) - where, however, the round letters have larger dimensions. The simple letters without serifs also recall in general terms the script of MADDOLI (2007), no.1.1, p. 205-207 [v. FABIANI (2015), p. 130], but the two texts have other characteristics that differentiate them [in I.Iasos 220 the letters have generally a more elongated shape and the round letters - theta, omicron - are smaller than the other ones, which does not happen in MADDOLI (2007), no 1.1]. Hicks, in NEWTON - HICKS (1890), assumed a dating in the middle decades of the $5^{\text {th }}$ century, and writes on p. 54: “... the letters are perfectly clear; they are of the best period, and are probably not much later than the Lygdamis inscription of which the date is about 450 BC". DITTENBERGER in Syll. ${ }^{2} 602$, on the other hand, wrote: Litterae Ionicae volgares non

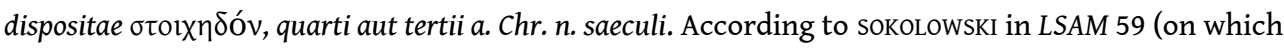
see below), the text belongs to the $4^{\text {th }}$ century BC.

11. .HOFFMANN (1898), no. 131, p. 59-60; MICHEL (1900), no. 724, p. 622; DITTENBERGER in Syll. ${ }^{2} 602$ (Lipsiae, 1900). Hicks' readings, as corrected by Dittenberger, were later accepted by BECHTEL (1905), no. 5517, p. 645, and are also to be found in Syll. ${ }^{3} 1016$ (Leipzig 1920, edited by F. HILLER VON GAERTRINGEN). The new supplements proposed by F. SOKOLOWSKI in LSAM no. 59, p. 148-150 (see below) have been then accepted in I.Iasos 220 and adopted from there by LE GUEN-POLLET (1991a), no. 41, p. 135-139 (with French translation); MCCABE, Iasos, no. 1; PIRENNE-DELFORGE (2005), no. 33, p. 11; LOMBARDI (2009), p. 97-98 (with Italian translation).

12. A report of the 2011 excavation of the agora can be found in ROMAGNOLI (2012), cf. esp. p. 13.

13. The most convincing parallels seem to be the scripts of the decrees PUGLIESE CARRATELLI (1985), p. 155 (= SEG 36, 983), and I.Iasos 1 , which are to be dated to the ' 60 s and ' 50 s of the $4^{\text {th }}$ century BC: FABIANI (2015), p. 131, 142-144 (script) and p. 252-253 (dating). The short vowel $\varepsilon$ is written in the

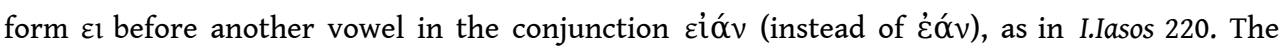
phenomenon is frequent in Attic inscriptions from the end of the $5^{\text {th }}$ until the middle of the $3^{\text {rd }}$ century BC, but the most numerous samples come from $360-320 \mathrm{BC}$, while a strong decrease is recorded after 300 BC: see THREATTE (1980), p. 147-152.

14. .้̌ $v \theta \rho u \pi \tau \alpha$, as already reported by Hicks in NEWTON - HICKS (1890), p. 55, and Dittenberger in Syll. $^{2}$, 602, p. 375, are cakes: Demosthenes, 18, 260; Harpokration, s.v.; Pollux, Onom. VI, 77;

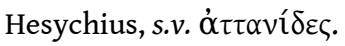

15. .Hicks in NEWTON - HICKS (1890), p. 55.

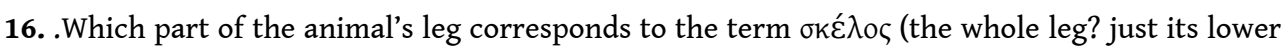
part?) is still an open issue: ЕКRотн (2013), esp. p. 115, n. 8 summarizes the different opinions; however, she is inclined to interpret $\sigma \kappa \varepsilon \dot{\lambda}$ os as a term referring to the whole hind limb. In this case, the priest is awarded "whichever leg he wishes", so it is not specified, as is sometimes the

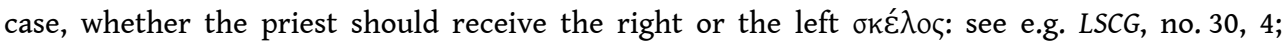
LE GUEN-POLLET (1991b), p. 17-18. 
17. .VAN STRATEN (1995), p. 118-141, with very useful literary references; EKROTH (2009), esp. p. 129. On the identification of the part of the animal called ó $\sigma \tilde{v} \varsigma$ some hypotheses have been previously expressed by LEGUEN-POLLET (1991b), esp. p. 20, who fully accepts, even in its more general interpretation, Hick's supplement $\dot{\omega} \varsigma \dot{\varepsilon} \kappa[\tau \dot{\varepsilon} \mu \nu] \varepsilon \tau \alpha$.

18. .So екRотн (2009), p. 129. See Pollux, Onom. II, 178 and 182.

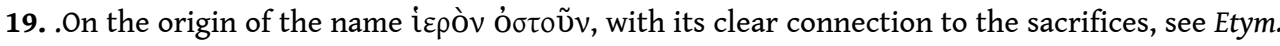

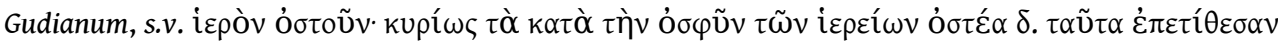

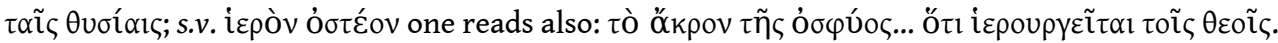
20. .It was the so-called "god's portion". For the literary sources on the ó $\sigma \varphi \tilde{u} \varsigma$, see DURAND (1989), p. 102; VAN STRATEN (1995), p. 121-141; EKROTH (2009), p. 129-130. Among the most eloquent passages, Aeschylus, $P V$, 496-499 may be mentioned: Prometheus claims to have taught mankind different kinds of divination; one of these is related to the signs that can be observed when god's portion is burning on the altar, which includes the thighs $(\kappa \tilde{\omega} \lambda \alpha)$ wrapped in the fat and the

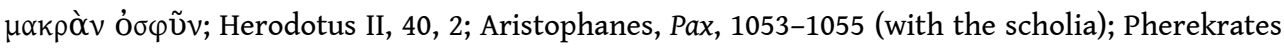
ap. Clemens Alexandrinus, Stromata VII, 30, 3 (fr. 28, ed. Kassel -Austin = fr. 23, ed. Kock): ... koì $\tau \eta ̀ v ~ o ́ \sigma \varphi \tilde{u} v . . . \psi \imath \lambda \eta ́ v$ : the ỏ $\sigma \varphi \tilde{u} \zeta$ that is offered is thus completely bare); Menander, Dyskolos, 447-

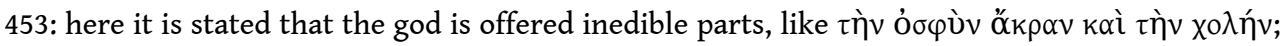

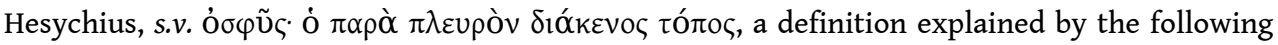
words of DURAND (1989), p. 102: “... the back begins where the ribs end. At the lower end it holds the kidneys and in the Greek view makes fat to compensate for the lack of protective flesh, since this entire zone, osphys, is a point of flexion and has very little to cushion it". Along with the thighs and the ó $\sigma \varphi \tilde{v} \varsigma$, other parts of the god's portion were the tail and the gallbladder: VAN STRATEN (1995), p. 121-128.

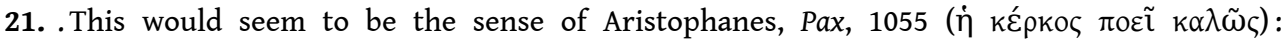
VAN STRATEN (1995), p. 122; EKROTH (2009), p. 148. The scholium on the verse 1055 reads: $\dot{\eta}$ oủ $\rho \grave{\alpha}$

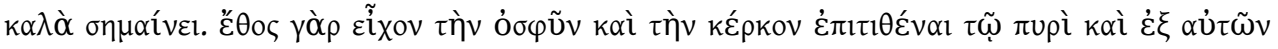

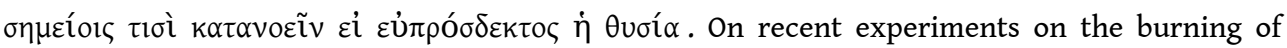
thighbones twice wrapped in fat see MORTON (2015).

22. .SO EKROTH (2009).

23. Sacred regulations that place the ó $\sigma \varphi \tilde{v} \varsigma$ among the portions to be given to the priest or to

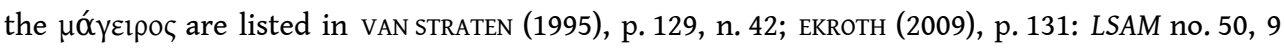
and 34; LSCG no. 96, 13-14; LSS no. 93, 1. Note that the bones offered to the gods are called ó $\sigma \tau \varepsilon \alpha$

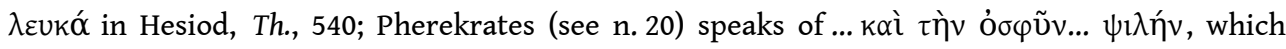
means "bare": they are therefore bones devoid of meat.

24. So already in LE GUEN-POLLET (1991), p. 20, n. 98; VAN STRATEN (1995), p. 129, n. 42.

25. The identification of the i $\varepsilon \rho \grave{\alpha} \mu$ oĩ $\rho \alpha$ with the ó $\sigma \varphi \tilde{v} \zeta$ is discussed and sustained, through a list of the sacred regulations that mention it, by DIMITROVA (2008).

26. .ЕКROTH (2008), p. 262.

27. .See e.g., LSCG 69, 26 (at Oropos); IG XII 4, 1, no. 298 A, 10; no. 306, 8-9; no. 315, 17-18 (at Kos). But see also Homer, Odyssey III, 179 and XXI, 267.

28. .DURAND (1989), p. 106-108; LE GUEN-POLLET (1991), p. 138-139. For this reason too, as EKROTH (2009), p. 145 says, the portion par excellence of the priest is the leg: the corresponding bone (the thigh) is in fact another portion strictly reserved to the god. See also EКROTH (2008), p. 268-269. GILL (1974), p. 127-133: in addition to the parts due to him, the priest is also given the god's

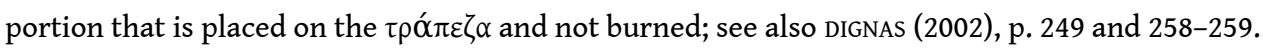

29. .See also IG XII 4, 1, 332, 24-36; IG XII 9, 189, 5-6; I.Mylasa 914, 1-4.

30. .On the formulae protecting inscriptions and particularly on the use in such a context of the verb $\alpha$ $\varphi \alpha v i ́ \zeta \omega$ see LOMBARDI (2010), p. 181-183. The pair "stele" - "written letters" as direct 
object of the verb $\dot{\alpha} \varphi \alpha v i ́ \zeta \omega$ is also present in the decree of the koinon of the Pernitai in honour of a man from Limyra: WÖRRLE (1991), p. $220=S E G ~ 41,1379,6-9$. Curses and fines against persons guilty of ruining or erasing epigraphs are particularly frequent in tomb inscriptions: see STRUBBE (1997) and HARTER-UIBOPUU (2014).

31. .GILL (1974), p. 132; LE GUEN-POLLET (1991a), esp. p. 138; PIRENNE-DELFORGE (2005), p. 11; LOMBARDI (2009), p. 97-98; PATERA (2012), p. 121; CARBON (2013), p. 382, n. 4. Note on the other hand that the

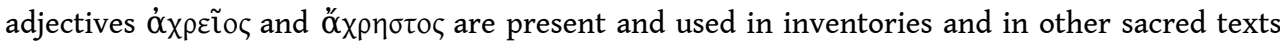
not so much in reference to objects awarded to priests, but to votives donated to the gods and subsequently kept in the shrines: regular checks of the state of conservation of the $\dot{\alpha} v \alpha \theta \eta \dot{\eta} \mu \alpha \tau \alpha$ lead sometimes to suggestions to provide for their restoration and repair: see LOMBARDI (2009), p. 104-107 and 125. GILL (1991), p. 19, believes that the same general idea must be behind the permission often given to the priest to take for himself the food offered on the $\tau \rho \alpha$ ó $\pi \xi \zeta \alpha$ : it means taking for himself what cannot still be good for the god.

32. .LUPU (2003), esp. p. 329 and 335-339 (among the cases see above all LSCG no. 88, 11-15; LSCG Suppl. no. 72A, 1-3; ibid. no. 108, 8-12; LSAM no. 73, 29-32; IG XII 4, 1, 319, 10-12: Lupu notes how the award of money to the god is indicated by the middle form of the verb $\alpha$ a $\alpha$ ox $\omega$ or by the verb $\dot{\varepsilon} \mu \beta \alpha ́ \alpha \lambda \omega) ;$ LSAM no. 12,14-17. The inventories of the treasures on the acropolis in Athens and in the Delian shrines also list money, even if it is by no means an essential part of them: see the indices put together by HARRIS (1995), p. 300-303, and HAMILTON (2000), p. 455-479; of the same opinion is also SASSU (2014), p. 4. On the offers of metal objects to the gods see PATERA (2012), p. 83-97.

33. See e.g. I.Erythrai no. 205, 17 and 20; LSCG no. 45, 2-7. See also IG XII 4, 1, 304, 30-36; 319, 5-9; $326,61-64$. On the fees and amounts paid in the sphere of worship, including payments to the priests, see soкоLOWSKI (1954), p. 153-159.

34. See e.g. in this respect IG $\mathrm{II}^{2} 1237,5-8$; $\mathrm{II}^{2}$ 1361, 4-7; RHODES - OSBORNE (2003), no. 37, 27-41:

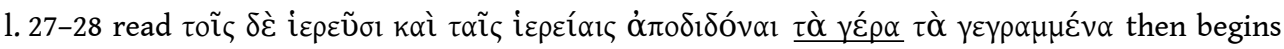

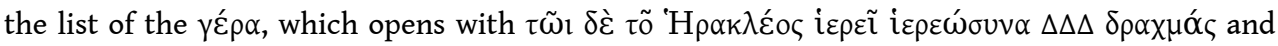
then goes on to list $\pi \varepsilon \dot{\varepsilon} \lambda \alpha$ os and a little further skin, leg and other portions.

35. .In the inscription recently found at Iasos and published by MADDOLI (2015) [but see also the extensive work of NAFISSI (2015)], which records the sale of the priesthood of the $\Theta \varepsilon \tilde{\omega} v$ Mń $\tau \eta$, it is prescribed, on the contrary, that of the objects placed on the $\tau \rho \alpha \dot{\alpha} \pi \varepsilon \zeta \alpha$, the priestess can take anything, except clothes and things made of gold and silver.

36. Our document is also informative about ritual practice. On the selection criteria of the epigraphs which will be included in the CGRN and on the necessary but complex action of defining the nature and content of such texts in order to determine their relevance to the project or not, see the observations of CARBON - PIRENNE-DELFORGE (2012); on the complex and unsatisfactory definition of "lois sacrées" see also GEORGOUDI (2010).

37. See in this respect PARKER (2004), esp. p. 60, n. 21; PARKER (2005), p. 63.

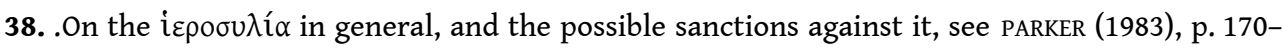
173 and more recently SCHIPPERHEIJN (2013), with previous references. A list of the possible actions

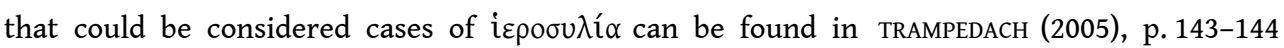
(samples at p. 157-165). Evidence on legal practice concerning i $\varepsilon \rho \circ \sigma u \lambda i ́ \alpha$ all over the Greek world is considered in COHEN (1983), 93-115 (for our text see p. 105, no. 2, 107-109: at Iasos the definition of this kind of offence evidently concerns not just acts involving theft, but also those implying a sacrilege), who concludes that it is not possible to formulate a precise technical definition of

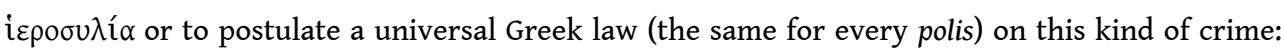

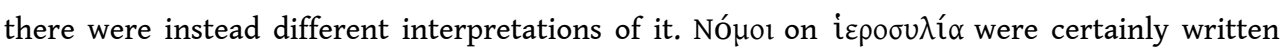
down in later times: see Syll. ${ }^{3}$ no. $578,50-51$ (Teos, $2^{\text {nd }}$ century BC); a law on the subject is 
mentioned in SEG 39, 729, 9-11 (Rhodes, $3^{\text {rd }}$ century BC); IC II 3, no. 2, 48-49 (Aptera, $2^{\text {nd }}$ century $\mathrm{BC})$.

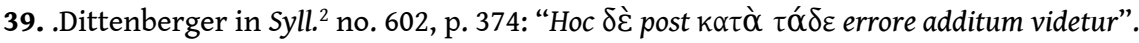

40. .LUPU (2005), p. 41-44.

41. .GEORGOUDI (1998).

42. .Syll. ${ }^{2}$, no. 602, p. 374, followed by Sokolowski in LSAM, no. 59, p. 149.

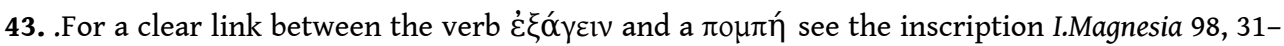
35: the $\sigma \tau \varepsilon \varphi \alpha \vee \eta \varphi$ ó $о$ ৎ together with the priest and priestess of Artemis Leukophryene must lead the $\pi$ ou $\pi$.

44. .I owe this indication to Mat Carbon, whom I thank.

45. .DENNISTON $\left(1954^{2}\right)$, p. 170-171. Very similar to this kind of $\delta \varepsilon$ seems to be the so-called "inceptive" $\delta \varepsilon$, which is found at the opening of a speech, and no connection with other elements seems to be required (ibidem, p. 172-173).

46. .Leases: SCHWENK (1985), no. 32, 2; IG II ${ }^{2} 2497$, 1: in both cases, after the heading, the first sentence contains $\delta \varepsilon$. Oaths: v. e.g. IG $\mathrm{I}^{3} 40,3$ and 21. Judicial courts: SEG 31, 629. Cultic regulations: $I G \mathrm{II}^{2} 4962$, 2. The formula appears sometimes to introduce specific decisions in the documents containing priesthood sales as well: ZPE 34 (1979), p. 211-213, no. 1 (Theangela); MADDOLI (2015), p. 103, 1. 4 and 7 (Iasos). A priesthood sale inscription recently found at Priene

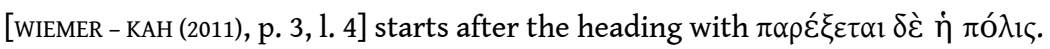

47. We have noticed above that the formula aiming at the protection of the text against defacing (1. 7-8) suggests that the practice of writing was already quite common at Iasos at the time when our law was promulgated (late $5^{\text {th }}-$ early $4^{\text {th }}$ century BC). For this reason, I wonder if the acute remarks advanced by Rosalind Thomas about the written laws in archaic and fifth century Greece [THOMAS (1995), p. 71-73 and (2005), p. 56] can apply to the London text, which is certainly one of the most ancient written documents from Iasos. Thomas has suggested that in the early phases of the Greek history not every law was written on stone, just the ones which were new or contentious and had not yet been universally recognized: accordingly, the ancient laws on stone are usually not substantive, but have mainly a procedural content, also establishing fines and penalties. Unlike the traditional customs of the community, such new laws needed to be protected, by the gods of course, but also through sanctions against possible defacing of the letters.

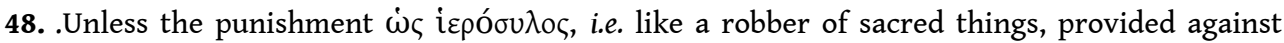
whom will eventually deface the stele or the letters, has led the proposer of the law to consider at this point the objects offered to the god.

49. .For some samples of amendments (in decrees) which could be detectable thanks to the arrangement of the text see LAQUEUR (1927), p. 44-47 and passim; see anyway the warnings of RHODES - LEWIS (1997), p. 25, n. 69 and p. 516-517.

50. IG XII 4, 1, 294 and 295 (two copies of the same priestly regulation, maybe a sale of the priesthood of Asklepios; see also 311); 298 and 331 (and perhaps 307-308 as well: sale of the priesthood of Hermes Enagonios); 302 and 319 (Aphrodite Pandamos and Pontia); 304 and 326 (Dionysos Thyllophoros); 305 and 320 (Herakles Kallinikos); 315 and 324 (Homonoia); 318 and 325 (Adrastia and Nemesis). On cults and priesthoods in Kos see PAUL (2013).

51. .It also happens at Iasos with another kind of text, a honorary decree for the sons of the Karian Peldemis, which was inscribed a second time more than a century after the first publication, and at least for a while the two copies were certainly both visible: FABIANI (2013), p. 317-322. 


\section{ABSTRACTS}

The contribution capitalizes on a careful re-reading of I.Iasos 220, a well-known cultic regulation concerning the rights of the priest of Zeus Megistos dating to the Classical period (now preserved in the British Museum), as well as on the fortuitous discovery during the 2011 Italian excavation campaign of a fragmentary stele preserving a portion of a slightly later copy of the same text. During its reuse, the letters in the central section of the London stone were purposefully erased, thus making the newly discovered fragment particularly valuable. The new edition proposed here in some cases corrects, and in others confirms - despite subsequent conjectures - many of the first editor's (E.L. Hicks) proposed supplements. The improvements on the reading of the text bring to light new details about priestly prerogatives and, in addition, all of the major problems posed by the document are discussed in the commentary.

en

Le présent article livre une relecture attentive de l'inscription d'époque classique I.Iasos 220 (conservée au British Museum), un règlement cultuel bien connu sur les droits du prêtre de Zeus Megistos. Des progrès dans la lecture ont été favorisés par la découverte fortuite, pendant les fouilles italiennes de 2011, d'une stèle fragmentaire conservant une partie d'une copie légèrement plus tardive du même texte. Lors du remploi de la pierre conservée à Londres, les lettres de sa partie centrale ont été intentionnellement effacées, ce qui rend le fragment récemment découvert particulièrement précieux. La nouvelle édition proposée ici corrige, dans certains cas, et confirme, dans d'autres - en dépit de conjectures ultérieures - nombre des restitutions proposées par le premier éditeur (E.L. Hicks). Les progrès effectués dans la lecture de ce texte contribuent à éclairer de nouveaux aspects des prérogatives du prêtre. Un commentaire aborde en outre tous les problèmes posés par ce document.

\section{AUTHOR}

\section{ROBERTA FABIANI}

Università Roma Tre

Dipartimento di Studi Umanistici

via Ostiense, 234

I - 00144 Roma

roberta.fabiani@uniroma3.it 